OCCASIONAL PAPER

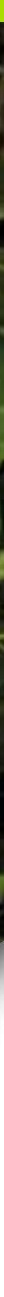

\title{
The gender box
}

\section{A framework for analysing gender roles in forest management}

Carol J. Pierce Colfer

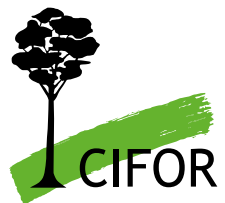





\section{The gender box}

\section{A framework for analysing gender roles in forest management}

Carol J. Pierce Colfer

Center for International Forestry Research

Cornell Institute for International Food, Agriculture and Development 


\section{Occasional Paper 82}

(c) 2013 Center for International Forestry Research All rights reserved

ISBN 978-602-8693-92-9

Colfer, C.J.P. 2013. The gender box: a framework for analysing gender roles in forest management. Occasional Paper 82. CIFOR, Bogor, Indonesia.

Photo by Diolo Celine

A woman harvesting the Gnetum (okok), Village Minwoho

\section{CIFOR}

JI. CIFOR, Situ Gede

Bogor Barat 16115

Indonesia

$\mathrm{T}+62(251) 8622-622$

$F+62(251) 8622-100$

Ecifor@cgiar.org

\section{cifor.org}

Any views expressed in this publication are those of the authors. They do not necessarily represent the views of CIFOR, the authors' institutions or the financial sponsors of this publication. 


\section{Table of contents}

Glossary of social science terms as used in this occasional paper iv

Acknowledgements $\quad$ vi

1 Introduction and methods 1

2 Results $\quad 5$

2.1 Macro scale 5

2.2 Meso scale 11

$\begin{array}{lll}2.3 \text { Micro scale } & 21\end{array}$

3 Conclusions and ways forward $\quad 35$

4 References $\quad 36$ 


\section{Glossary of social science terms as used in this occasional paper}

Addressing practical gender needs

Addressing strategic gender needs

Asset rights

Bilateral

Collective action

Enculturation

Enculturators

Essentialist

Great Tradition

Hegemonic

Hegemonic

masculinity

Hetero-normative conjugal norm

Liminal

Little Tradition
These concern daily and widely accepted needs, such as for food, shelter, health, education; they are valued but providing them is unlikely to alter gender inequities substantively

These concern questions of power and voice-at all scales, from intra-household to international; though more difficult than purely practical approaches, they are more likely to result in serious positive change

Include 'ownership, use, decision making and documentation over land, housing, material assets, livestock and financial assets'; see Jacobs et al. 2011. Gender differences in asset rights in KwaZulu-Natal, South Africa. Washington, DC: International Center for Research on Women, p. 31.

This kinships system refers to the practice of tracing descent and inheritance through both parents

both the process by which voluntary institutions are created and maintained and the groups that decide to act together; see Pandolfelli, L. Meinzen-Dick, R. and Dohrn, S. 2007. Gender and collective action: a conceptual framework for analysis. Collective Action Working Paper 64: 57.

The process of bringing up children within their cultural context

Those who bring up children within their cultural context

The tendency to see a characteristic as inherent. Women, for instance, are seen by some as inherently closer to nature than men (an essentialist position)

A body of knowledge and norms cultivated in schools and temples, considered carefully by the 'reflective few', by the philosopher, theologian and literary persons, consciously cultivated and handed down; see Redfield, R. 1971 (original 1960). The Little Community, Peasant Society and Culture. Chicago: University of Chicago Press.

The social, cultural, ideological or economic influence exerted by a dominant group

Widespread views of men's roles that reinforce male dominance; see Bannon and Correia 2006. The other half of gender: men's issues in development. World Bank, Washington, DC.

This phrase refers to a governmental expectation that benefits will flow to a couple (one man, one woman) in an enduring union that links the couple to the nation state; see Elmhirst, R. 2011. Migrant pathways to resource access in Lampung's political forest: Gender, citizenship and creative conjugality. Geoforum 42: 173-18

An 'in between' state, transitional

A body of knowledge and norms that evolves and maintains itself in the daily lives of the unlettered, the 'unreflective many', in village communities; see Redfield, R. 1971 (original 1960). The Little Community, Peasant Society and Culture. Chicago: University of Chicago Press. 
Macro scale

Management

Matriclan

Matrilineal

Matrilocal residence

Meso scale

Micro scale

Mother roasting

Narratives

Narratives of modernity

Narratives, policy

Patriclan

Patrilineal

Patrilocal residence

Polygamy

Polygynous

Purdah

Scheduled caste

Swidden
This refers to issues of global concern

Human behaviours designed to affect something. In the case of forestry, traditionally, management has focused on maintaining or increasing production. There is greater concern now for ecological and social implications of management.

A clan in which descent is traced through women (mother to daughter to granddaughter)

Systems in which inheritance and kinship affiliation typically flow from mother to daughter; with maternal uncles and brothers typically having more authority than in patrilineal systems

A pattern of residing with or near the wife's family after marriage (also called uxorilocal residence)

This concerns issues ranging from the national level to a supra-village scale (a district, a particular forest)

This refers to issues ranging from the village through sub-groups within a village to intra-household issues

A custom in many parts of Southeast Asia, which involves keeping new mothers heated for varying periods after giving birth, as a protective action.

Coherent ways of linking and providing a rationale for events

Stories that emphasise a unilinear, step wise progression from primitive to modern; e.g. 'high modernism' described fully in Scott, J.C. 1998. Seeing like a state: how certain schemes to improve the human condition have failed. Yale University Press, New Haven, CT, US.

Stories used to simplify reality for the purpose of making/reinforcing policy decision making. See Roe, E. 1994. Narrative policy analysis: theory and practice. Duke University Press, Durham, US.

A clan in which descent is traced through men (father to son to grandson)

Systems in which inheritance and kinship affiliation typically flow from father to son.

A pattern of residing with or near the husband's family after marriage

Marrying multiple partners (polygyny refers to multiple wives; polyandry to multiple husbands)

Having more than one wife

The practice of secluding women within the home, restricting their movement and covering their bodies, hair and, in some cases, faces.

The Indian government classifies the low-ranking castes (hierarchical social groupings specified within Hinduism) by this phrase.

The food crop component of a system in which forests or grasslands are cleared and used for a shorter amount of time than they are left fallow. 


\section{Acknowledgements}

This work was commissioned and financially supported by the CGIAR Research Program on Forests, Trees and Agroforestry (CRP6) and the gender programme of the Center for International Forestry Research in Bogor, Indonesia. Special thanks go to Esther Mwangi for supportive and constructive supervision. I am grateful for other CIFOR colleagues' support, as well as those at the Cornell Institute of Food, Agriculture and Development, in Ithaca, New York. I also recognise and appreciate Cornell University's excellent library facilities. Heartfelt thanks go as well to Seema Arora-Jonsson, Purabi Bose, Jeannette Gurung, Melissa Leach, Cynthia McDougall, Ruth Meinzen-Dick, Rebakah Minarchek and Maureen Reed whose inputs have truly improved the quality and coherence of this Occasional Paper (though I alone bear the responsibility for any remaining errors). 


\section{Introduction and methods}

$\mathrm{W}$ ithin the world of professional forestry, there has been a growing recognition that gender roles, knowledge and interests have been under-acknowledged (e.g. Reed and Christie 2008, Lidestav and Reed's 2010 special issue of the Scandinavian Journal of Forest Research, Pottinger and Mwangi's 2011 special issue of International Forestry Review). Two changes have stimulated this recognition. First, foresters' concerns have evolved in such a way that they now see forests more holistically. Many now recognise, and try to incorporate into their management, elements such as biodiversity, ecological processes and human livelihood concerns. ${ }^{1}$ The second change emerges from the first. For centuries, forestry, focused as it has been on timber, has been seen as a male professionand indeed it has been in many parts of the world (cf. Porro and Stone 2005, Bolaños and Schmink 2005). But when one begins to look carefully at human subsistence within and near forestsparticularly tropical forests-women's involvement and interests become obvious.

Foresters ${ }^{2}$ are recognising a) that they need to do a more thorough job of taking women's knowledge, roles, interests and goals (and in many places, men's as well) into account, and b) that they don't really know how to do it. This need derives from the desire to manage more effectively. To manage well, one may:

1 Though Reed and Christie (2008) stress the degree to which gender has been ignored, perhaps even more assiduously, in 'the North' than in 'the South'. They argue that forestry in the West could learn much from gender studies in developing countries.

2 Agricultural scientists represent another category that has under-acknowledged the value of addressing women's involvement. Much of the livelihood activities within forests depends on swidden agriculture-what is in reality an agroforestry system; and women typically play significant roles within such systems (e.g. Fresco 1986; Colfer et al. in press).
- need to understand the systems-here, the social systems - that affect forests to maximise efficiency, and minimise conflict and related economic losses.

- want to take advantage of the expertise/ knowledge, energy and commitment available - particularly, that of women, which have been comparatively ignored.

- believe there are ethical issues involved, that a sense of fair play/justice also requires attending to the forest-related needs of the female half of the human population, as well as of men who do not somehow 'fit' (by ethnicity, class or even behaviour, see Reed 2010). ${ }^{3}$

- note women's valued social roles as bearers and (usually) enculturators ${ }^{4}$ of the next generation-of serious consequence for forest sustainability.

- take into account (and sometimes work to alter) relations between women and men, in decision making, labour, access, control and power, which shape whether, how and which people benefit from forest management.

This analysis is designed to clarify key social issues foresters need to address if they want forest management to benefit both the trees and the people who live among them. My emphasis has been on tropical forests and their residents. I hope the analysis will be of use to forestry policy makers, researchers, managers of production and conservation forests, project and NGO (nongovernmental organisation) personnel who work in forest contexts. I have become convinced that the sustainability of forests depends fundamentally on better treatment of the people living in and around them. Half of those are women.

3 Inattention (and warped, negative attention) to men's roles in development represents another danger, one I hope to begin to avoid here.

4 See Glossary for my uses of social science terms like enculturation. 
Although this analysis emerged from an examination of people living in forested contexts, the framework in fact applies more broadly. There is obvious relevance for gender in agriculture, fisheries, conservation and other natural resource management contexts. Most fundamentally, I have sought to identify the kinds of factors that condition gender differentials in participation in decision making in forest use and management (writ large), ${ }^{5}$ and to cluster them into manageable categories (see Tables 1 and 2), which can guide us as we seek a more equitable and effective approach in managing forests.

The gender box (Figure 1), referred to in the title of this Occasional Paper, is partially designed to reflect the organisation of the coming discussion. But it also can serve as a handy reminder, a mnemonic device, of the importance of key issues (centre right), scale (centre), and time (left to right of the figure) in our attempts to address gender. All 11 issues have some relevance at all three scales; but I have opted to emphasise a particular scale for each issue, based on materials coming from the literature.

The third dimension, which emphasises the past, present and future, has not, to my mind, been sufficiently highlighted in this document; but there is growing awareness of the importance of both history (e.g. Federici 2004, Andaya 2006, Wardell $2012)^{6}$ and people's dreams of the future (e.g. Wollenberg et al. 2001, Nemarundwe et al. 2003, Cronkleton 2005, Djoudi and Brockhaus 2011) in forest management.

The diversity in the world's forests does not allow a tidy, cookie-cutter list of items one can check off (despite the fairly tidy tables provided). Instead, I have pulled together topics that recur, and, in the text, provided examples of what has been found to be relevant in forests where gender has been studied. This paper provides a simple organising framework, alerts readers to potential areas of interest through a partial literature review and

5 I include within 'forest use and management', local people's involvement in swiddening, for instance. Findings on gender phrased as 'agricultural' are often also observably relevant for forests, and are thus included here.

6 Special thanks to Maureen Reed for reminding me of this issue in her review. hopefully aids any given reader in maximising his/ her creativity to deal with particular people in any real forest.

The analysis builds on three recent literature reviews. The first involved an examination in 2011, of the perceptions of marginalised folks, including women, of their own governance (Colfer 2011); the second grew out of a careful perusal and synthesis (Colfer $e t$ al. in press) of gender-related information in 36 chapters of an evolving book on swidden fallows in Southeast Asia (Cairns in press); and the third has been conducted throughout 2012, some of which is reflected in Colfer and Minarchek (2012) — a review of the methods available for studying gender in forests. Our metamethod for this latter study involved examining literature obtained through internet searches using the key words 'woman'/'women', 'forests' 'woman and forest'/'women and forest', 'men and forest', and 'gender and forest'; we prioritised the literature from 2000 onwards. I also sought out and reexamined books I knew to include important forest-related gender findings; and I mined my own experience.

In the literature review, I systematically identified issues that emerged in these writings, of relevance for the questions of who-men or women?-is involved in forests and their management, along with how and why. These issues I recorded in an Excel file. My analytical process in developing this framework was first to examine the 42 issues that emerged from these diverse readings and to cluster them into the 11 topics represented in the gender box.

The gender box acknowledges our ability to look at any of these issues at any scale. But considering the needs of foresters specifically, further clustering these 11 issues into three scales-macro, meso and micro-provided a convenient organisational framework. It has also allowed me to emphasise the importance of looking at all three levels; and to provide examples of issues that might best be addressed at each. I opted to examine below, two at the macro level, four at the meso level and five at the micro level (see Tables 1 and 2, for some key research questions pertaining to these issues). This uneven clustering emerged from the issues identified in my readings. But it also reflects my own sense, based on personal experience, that the 


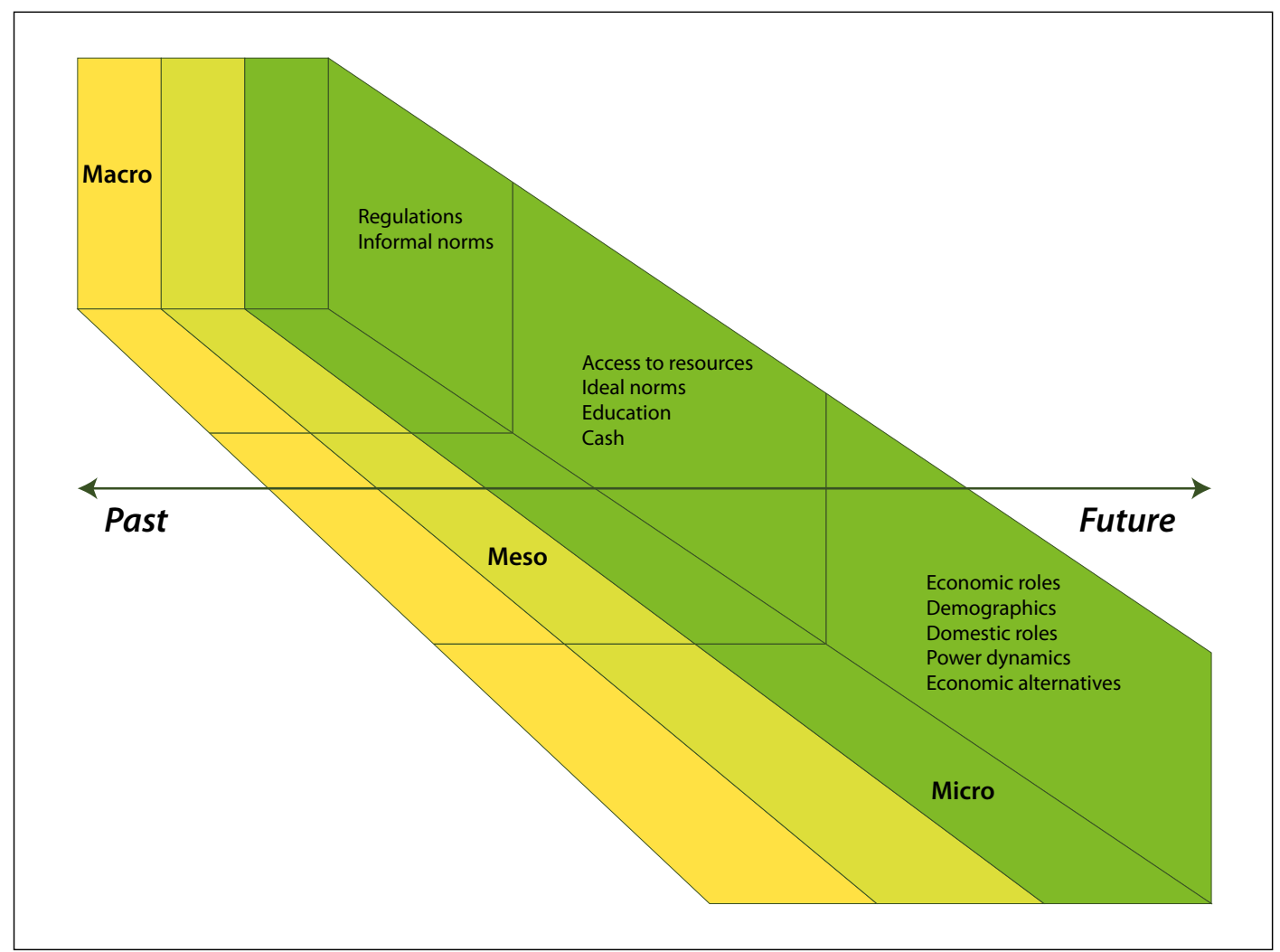

Figure 1. The gender box

micro level is the most powerful in determining what actually happens in a given forest. ${ }^{7}$ The third dimension, which is only included here peripherally, warrants further attention-reaching back into the past and thinking forward into the future. ${ }^{8}$ I conclude the paper with some thoughts on gaps and ways forward.

Our mandate, when using this gender framework, is to examine and consider which of these forceswhether formal or informal-are affecting men and women in the areas where we work. How are global policies and laws and global values, for instance, affecting local men and women, respectively? And are there ways to use them to leverage better success at the local level? The same

7 We are all enmeshed in gender systems of our own. Although I make every effort to approach this research topic as objectively as I can, none of us can fully escape our own experience and resulting biases.

8 This time orientation was implicit in much of the work conducted within CIFOR's Adaptive Collaborative Management programme (through context studies that included historical trends; and through future scenarios and visioning work) in the early and mid-2000s. Reed and Bruyneel (2009) call for such an orientation explicitly. mandate exists at the meso and micro scales. The variation from place to place expands exponentially as we move down in scale.

Table 1. Key gender issues emphasising aspects addressed here

\begin{tabular}{|c|c|c|c|}
\hline Gender Issues & Macro & Meso & Micro \\
\hline Formal laws/policies & $x$ & & \\
\hline Cultural/religious trends & $X$ & & \\
\hline $\begin{array}{l}\text { Access to natural } \\
\text { resources }\end{array}$ & & $x$ & \\
\hline Norms of behaviour & & $x$ & \\
\hline Access to education & & $x$ & \\
\hline Access to cash & & $x$ & \\
\hline $\begin{array}{l}\text { Day to day economic } \\
\text { roles }\end{array}$ & & & $x$ \\
\hline Demographic issues & & & $x$ \\
\hline Domestic roles & & & $x$ \\
\hline $\begin{array}{l}\text { Intra-household power } \\
\text { dynamics }\end{array}$ & & & $x$ \\
\hline $\begin{array}{l}\text { Available economic } \\
\text { alternatives }\end{array}$ & & & $x$ \\
\hline
\end{tabular}




\section{Table 2. Framework for analysing gender implications in forest and tree management}

Consider how these factors function in your site. In what ways might they hinder or reinforce your work at the field level? Do these topics actually transcend scales?

I. Macro scale - broadly based, global 'rules' that affect people's interactions with forests

A. Are there formal, global laws and policies that affect local people and forests? How?

B. What religious traditions, narratives of modernity or equity, or other less formal, global, intellectual forces affect local people and forests?

II. Meso scale - Social patterns from landscape to national levels that influence people's behaviour in relation to forests

A. How is access to resources gendered? Are there broadly accepted notions that influence land tenure, inheritance and residence?

B. What are the gendered norms of behaviour that affect people's interactions with trees and forests (e.g. masculinity ideals, seclusion of women, witchcraft beliefs)?

C. Are there gendered differences in access to education (both formal and informal)? How do they affect men, women and forest management differently?

D. How important is cash in the regional system, and how has this affected men and women differently?

III. Micro scale - human behaviours from household to village levels that affect forests and people's well being

A. How do men's and women's day to day economic roles differ-especially in terms of agriculture, forest products, livestock?

B. What gendered demographic issues affect forests and people locally (e.g. migration, population changes, access to birth control)?

C. What essential/valued domestic roles do men and women play, respectively (e.g. cooking, hygiene, child and elder care, health, fuel wood collection) that affect their respective involvement in forests?

D. What patterns are identifiable in intra-household power dynamics? In what ways do men's and women's interests conflict and converge? Are there bargaining strategies used by each?

E. What are the features (e.g. collective action, access to technology, distribution of benefits, time constraints/conflicts) of locally available, alternative economic strategies designed to enhance people's livelihoods, trees and forests? How do these differentially affect men and women? 


\section{Results}

I $\mathrm{n}$ this framework, these three scales-macro, meso and micro-comprise layers of influence on any given woman (many affect men too). The boundaries between scales are fluid and fuzzy; they represent more continua than discrete layers and, importantly, they mutually interact: ${ }^{9}$

- Within the macro level, I have opted to discuss issues of a) policy, law and other formal conventions, and b) less formal, but powerful cultural, religious and 'modern' notions.

- The meso scale is the most geographically diverse, ranging from formal administrative units (the state and below), to the supra community area inhabited by a particular ethnic, caste/class or religious group. At this scale, significant issues addressed include a) land tenure and access to resources/assets, b) norms about gender and age, c) educational opportunities and d) changes from subsistence to cash economies.

- At the micro level, the literature highlighted five broad clusters of issues: a) economic roles, b) local demographics, c) domestic roles, d) intrahousehold power dynamics and e) alternative paths for life-changing improvements.

These classifications allow us to simplify reality, and think in terms of specific issues that foresters can look at, using different methods through varying conceptual lenses. It is important to remember that each of the issues discussed also has implications at the other scales and that there are interactions among scales.

\subsection{Macro scale}

As we consider factors conditioning gender differentials in participation in forest use and management, many analysts assume the macro scale to be the most relevant. Such analysts argue a) that this scale provides the context and backdrop against which individual decisions are made and within which openings for participation do or do not exist; and b) that macro-level attention can support the forces for greater equity within nations. These are both valid perspectives, with varying degrees of impact on the ground.

Just as forest policies may bear little resemblance to realities in the field, so it is with policies designed to address gender. We need to consider the interplay among scales. Tsing (2005) uses evidence from Borneo's forests to demonstrate how macrolevel forces influence local realities, but she also finds that such influence is moderated, adapted and changed in interaction with realities on the ground. See Gezon's (2012) work in Madagascar on women's dominance in khat production and links to international markets; Dolan (2002) links the weakness of the state with the intimate violence of men in northern Uganda; Schroeder's earlier work (1999), tracing the influence of development fads on gender relations in the Gambia, pre-dates but mirrors these analyses.

At this scale, I examine two broad topics: 1) formal laws and policies; 2) other less formal, global, intellectual forces (religion, culture and narratives of modernity).

\subsubsection{Laws and policies}

I begin with gender-relevant international agreements, and then proceed to discuss some of the central topics that have been addressed as policy issues at the international level. The central topics include land tenure and assets, collective action, empowerment, climate change/disaster
9 Cf. Pigg (1996) who phrases this scale issue thusly, village) is itself a translocal (or transnational) space. Locality is constituted in and through relations to wider systems, not simply impinged upon by them. We are more accustomed to noting this for economic systems - for instance, in discussing the organisation of peasant household production in its relation to capitalism and markets---than for systems of signification' (p. 165). Or see Tsing (2005) whose conception of 'friction' highlights where the 'rubber meets the road' as local communities encounter broader influences. 
relief, education, and health and family planning. My goal here is to highlight the impacts of policies and laws, but also to illustrate how unevenly they do and do not 'trickle down'.

The numbers of international agreements that potentially affect gender have skyrocketed in recent decades. CEDAW (the Convention on the Elimination of All Forms of Discrimination against Women) is an early agreement that went into effect in 1981 and continues in force internationally. Two of the seven Millennium Development Goals (2000) address women directly: promoting gender equality and empowering women (3) and improving maternal health (5). Others have clear implications for women's well being: eradicating extreme poverty and hunger (1), achieving universal primary education (2), reducing child mortality (4) and combatting HIV/AIDS, malaria and other diseases (6); some analysts also argue, controversially, that ensuring environmental sustainability (7) has more relevance for women than for men.

FAO's 2011 report on The State of Food and Agriculture, the 2012 UN Commission on the Status of Women, a draft Global Strategic Framework for Food Security and Nutrition of the UN Committee on World Food Security and the 2009 UN International Assessment on Agricultural Knowledge, Science and Technology report are indicative of recent international concerns about women in agriculture and development. All ' ... emphasise the growth and changes in women's involvement in agriculture and rural development' (Tripathi et al. 2012), which in turn reflects dynamic forces within forests. Similar legal processes have been underway at the national level in many countries.

Implementing CEDAW has proved more difficult than signing it. The experience of China, India, Ghana and South Africa illustrates the difficulties of trying to change gendered behaviours and beliefs (Pruitt 2009). Pruitt notes many examples of legal progress (from the equity standpoint), without accompanying progress on the ground.

Access to land and other assets-Land (on which there is often forest) is a prime example of legal progress without equity on the ground. ${ }^{10}$ In India, for instance, significant legal changes have favoured women's land ownership; but still some $90 \%$ of the female labour force is concentrated in agriculture, and most women own no land (cf. Nussbaum et al. 2003). Some policies designed to help actually hurt: see Bose (2011) on the unanticipated and adverse effects of India's Forest Rights Act on Bhil tribal women's land rights in Rajasthan.

In Latin America, evidence has surfaced that the gender asset gap may have been exaggerated in that part of the world. Deere et al. (2010), who examined women's assets in 11 countries in Latin America, found that many surveys focused on ownership by household heads (predominantly male). But these authors found that women in male-headed households often also own property not captured in such surveys. Still, overall, the global tendency is for women to have fewer and less clear rights to land and other natural resources, and to be particularly dependent on the commonsoften including forests_-and on marginal lands (World Bank 2009; cf. Rocheleau et al. 1996).

The gender situations in Ghana and South Africa are 'less positive' than in India and China (Pruitt 2009). In Ghana, for instance, women have few rights to land, even though they produce $70 \%$ of the food and are responsible for $90 \%$ of the food chain.

Collective action-There have been some successes: China encourages women's federations, for instance; India's policies have supported self-help groups, with considerable success among rural women, as have Ghana and South Africa (Pruitt 2009). Such self-help groups organised in a top-down fashion-

10 For discussion of women's comparative lack of rights to forest lands and related decision making, see Bandiaky-Badji's (2011) historical coverage of related policies and practices in Senegal's forests, where '(w)omen represent $39 \%$ of the active population, are in charge of $90 \%$ of domestic work and $85 \%$ of agricultural work' (p. 187). Tenure issues are also stressed by Mwangi and Mai (2011), who summarise a special issue on gender and forests (IFR, volume 13, no. 1). See also report by the High Level Panel of Experts (2011), which includes attention to women's global agricultural disadvantages, with adverse impacts on food security and nutrition. These authors also note the tendency for women to lose access to secondary rights when primary rights to land are formalised. 
and also of clear micro-level significance-are common globally. Veuthey and Gerber (2010), for instance, positively assess women's use of community interest groups - which have been encouraged by the government-in southern Cameroon.

The community forest user groups (CFUGs) of Nepal, which now have both conservation and livelihoods functions, began as governmentinitiated conservation interventions - with substantial urgings from international donors. Such groups have now expanded dramatically into a functioning grassroots network of around 18000 CFUGs (IRIN 2012) in which women's roles have achieved greater recognition under certain circumstances (cf. Agarwal's earlier emphasis, 2001, on women's lack of voice), with more recent and somewhat more encouraging analyses: Timsina 2003, Dangol 2005, Agarwal 2010, Lewark et al. 2011). ${ }^{11}$

Empowerment-Ultimately, if women's capabilities and concerns are to be addressed adequately in forests, women will need a stronger voice. Tripathi et al. (2012) have analysed efforts to empower women, seeking 'transformative changes in both public policy and practice'. They identify four mutually supporting elements for this transformation to take place:

- Collective action as key to economic and social empowerment

- Access to productive resources

- Economic empowerment as insufficient (underlying gender inequalities must be addressed)

- Disaster resilience and risk reduction approaches must be gender-sensitive and integrated with development interventions

Climate change and disaster relief-Many have urged greater attention to gender in efforts to deal with climate change:

11 This issue demonstrates clearly the multiple scales at which gender issues play out. Moving down from the macro level, recent findings, for instance, suggest that mixed groups of men and women perform best in forest management; see Mwangi et al. (2011) and Sun et al. (2011) who use data from IFRI (International Forestry Resources and Institutions), to compare outcomes among user groups dominated by men, by women, or mixed groups, in Kenya, Uganda, Bolivia and Mexico. Benjamin (2010), however, documents continuing marginalisation of women's views in mixed community forest management groups in Thailand.
'Differentiated power relations between men and women and unequal access to and control over assets mean that men and women do not have the same adaptive capacity; instead, women have distinct vulnerability, exposure to risk, coping capacity and ability to recover from climate change impacts'12 (World Bank 2009).

One strategy has been the development of a 'vulnerability capacity index' (Ahmed and Fajber 2009) for use in assessing women's and men's respective vulnerability to climate change; others, in Tajikistan, provided training in disaster preparedness and climate change (Tripathi et al. 2012), which led to women's empowerment more generally (see also Oxfam 2010).

Of particular interest in forests, of course, is the abundant recent work on REDD+ (Reducing Emissions from Deforestation and Forest Degradation). The unanimity with which women's interests appear to have been ignored to date is deafening (Brown 2011, on women's absence from policy in Cameroon; WOCAN 2012, on Nepal; or Mustalahti 2011, more generally). MacLellan (2009), for instance, found only nine separate articles using the word 'gender' out of 1167 articles in the top 10 climate change journals addressing 'climate change adaptation'. Djoudi and Brockhaus's (2011) micro-work on this global problem in Mali represents a striking exception: they examine and document the differing interactions with natural resources, different ideal futures and different needs of men and women as the climate changes. Unusually and valuably, they also note intra-community ethnic, class and subsistence differences in perceptions and practice. One likely adverse impact of REDD+ policy and implementation is greater pressure applied to shifting cultivators (see e.g. Bellassena and Gitz's simplistic 2008 suggestion to pay small sums to shifting cultivators to stop swiddening). Shifting cultivation is an agroforestry system in which women typically play particularly vital roles.

Education and training-Although women's education has been shown to have powerful

12 Although Terry (2009) supports attention to this subject, she cautions against seeing and portraying women only as victims. See also a 'business case' for attending to gender in climate change more meaningfully (UN-REDD Programme 2011). 
effects on a range of development outcomes, globally (Behrman et al. 2012a), there is also ample evidence that illiterate women in forest communities have a dramatically under-recognised store of useful knowledge; they also often pass this along to their children and grandchildren (see discussion below at meso scale). Still, the SIGI (Social Institutions and Gender Index) includes educational outcomes as the first of its four components (labour market outcomes, job quality and fertility rates are the other three, OECD 2010). Lower female educational achievement is closely correlated with early marriage (Behrman et al. 2012a), which can create a self-perpetuating cycle that offers no advantages for either people or forests.

Effective attention to women's education appears to be more common in Latin America than in Africa or Asia. In the Caribbean, girls outnumber boys in school 75/25 (Chevannes 2006); I observed a similar, if somewhat less dramatic, pattern of inequity in school attendance among the forest-dwelling Kenyah of Borneo-but these are exceptions to the general rule.

Extension systems also suffer from such genderbased inequities; many are marked by serious male bias in agriculture and aquaculture extension and training opportunities (see Ahmed and Fajber 2009, for Gujarat, India; Quisumbing et al. 2001, on Sumatra and Ghana; World Bank 2009, for much of Africa). Forestry has an even more dismal track record (see Ngono and Ardayfio-Schandorf 2007, on this issue in Africa).

Health and family planning-Ironically, although there is abundant literature on health and women generally, and an urgent need for greater attention to the health of women in forests (Allotey et al. 2008, Colfer et al. 2008, Wan et al. 2011), the health literature is heavily weighted toward urbanites. Discussion of reproductive health issues was effectively taboo in many policy and development circles for several decades, ${ }^{13}$ but there

13 Reasons included heavy-handed policies in India and China to reduce population growth in the mid twentieth century; complaints by Third World women about global pressure on population reduction without corresponding attention to western consumption patterns (e.g. at the 1985 International Women's Conference in Mexico City); the election of US presidents hostile to the idea of women's controlling their own bodies; among others. has been a growing willingness to put it back on the policy agenda recently. The ecological value of maintaining low population density in forested areas is obvious; and forest women represent an under-served population.

Although the potential dangers of top-down population control programmes are clear (including female disempowerment), there are many potentially positive impacts of such programmes if implemented with care and attention to people's needs and desires. There has been recent, encouraging interest in family planning efforts linked to conservation. A successful programme in Gombe Park, Tanzania, emerged partially in response to local demand (Mavanza and Grossman 2007). USAID's Office of Population and Environment has had a series of such activities in Madagascar and the Philippines (D'Agnes and Margoluis 2007). Jenny Blair of the Indonesian NGO, Alam Sehat Lestari, describes its programme linking health and conservation in Wan et al. (2011). On the other hand, Yen (2009) analyses a Shan community in China where women were kept out of reproductive policy making in part by their illiteracy, while male policy makers from top to bottom misrepresented women's knowledge and behaviour for political gain.

Laws, policies, global development and conservation interests clearly can have significant effects on gender and forests locally; but it's equally clear that the effects are not always those intended, that there is ample 'opportunity' for nonaction, diverted action and adverse unintended consequences. These range from Schroeder's (1999) dramatic and instructive documentation of the gender impacts in Gambia-as the development community's interests shifted from gardening (for women) to agroforestry (for men) to simple cases like Laderman's (1996) observation that US Peace Corps' design of a fancy new market in Malaysia effectively transferred market access from local women to men. Such unintended effects often result from the ways apparently 'uniform', well-meaning global efforts intersect with mesoand micro-scale gender relations in resource access, use and control. 


\subsubsection{Informal intellectual trends (religious, cultural, 'narratives of modernity')}

More than half a century ago, Robert Redfield (1971 [original 1960])—-though writing within the anthropological language of the time-helped lay the groundwork for our present-day thinking about multiple scales with his notion of 'great traditions' and 'little traditions'. ${ }^{14}$ Present-day writers like Paulson and Gezon (2004), Tsing (2005) and Scott (2009) have moved us further along in recognising the mutual interactions among scales. We now recognise that Redfield's Great Traditions are less monolithic, less coherent perhaps, than what he envisioned in their effects on his 'Little Traditions' (local, day-to-day manifestations). But recognition that global or regional cultural notions affect, and are affected by, local realities remains. Here I highlight several of the recurring themes: hierarchy, hegemonic masculinity, nature and nudity, formal religion and notions of modernity.

Hierarchy-From the perspective of gender in forests, many authors have noted the adverse effects of broadly accepted, explicit hierarchical ideals that disadvantage, and assign lower value to women, particularly in East and South Asia (cf. Federici's 2004 Euro-centric view). Gupte (2004), for example, examines how gender stratification affects participatory environmental policy-making, based on a comparison of community forestry in four Indian communities (two in conservative Rajasthan and two in Maharashtra). The latter, less stratified region has better indicators for women's literacy, higher age at marriage, and lower fertility and infant mortality rates, as well as a history of pro-active female involvement in political action. There is also less female involvement in forest management in the more conservative Rajasthan.

14 Redfield wrote of peasant communities, as part of civilisations: 'In a civilization there is a great tradition of the reflective few, and there is a little tradition of the largely unreflective many. The great tradition is cultivated in schools and temples; the little tradition works itself out and keeps itself going in the lives of the unlettered in their village communities. The tradition of the philosopher, theologian, and literary man [sic] is a tradition consciously cultivated and handed down; that of the little people is for the most part taken for granted and not submitted to much scrutiny or considered refinement and improvement....The two traditions are interdependent. Great tradition and little tradition have long affected each other and continue to do so'. (Redfield 1971 [original 1960]), pp. 41-42.
Among some groups, limiting women's work outside the home is seen as a mark of higher status. The northern Indian Yadava caste-officially described as 'backward' - tried to raise caste status by limiting women's work outside the home, including in forests (Jassal 2012). Hull (1996) reports similar encouragement of domesticity among the Javanese middle class, as do Djoudi and Brockhaus (2011) among higher status pastoral groups in Mali. ${ }^{15}$

\section{Hegemonic masculinity_A fair amount of} recent scholarship on men in gender studies has emphasised the geographically broad-based notion of 'hegemonic masculinity', which is seen as creating and/or reinforcing gender hierarchies. This gendered, masculine ideal mandates a male role as protector, provider and rightful dominator within families (Moore 2009). Barker and Ricardo (2006) link increasing violence (warfare, domestic abuse) and criminality in sub-Saharan Africa with changing sex roles that no longer allow men to perform this idealised form of masculinity (also noted by Silberschmidt 2001), for East Africa; Amuyunzu-Nyamongo and Francis 2006, in Kenya; Dolan 2002, for wartorn northern Uganda). Richards (2006) discusses the complexities of warfare and young men's roles, as they relate to powerful cultural features of marriage, sharecropping (and its antecedent, slavery) and gendered social grouping in the forests of Sierra Leone and Liberia-much of which he sees as affecting West Africa more generally. Chevannes (2006) discusses the functioning and effects of hegemonic masculinity in the Caribbean.

Nature and nudity_Although notions of women's closeness to nature have long been discussed, there is no unanimity of opinion (from Pierce 1971, who decried the notion to Shiva 1989, who celebrated it, and back to Leach 2007, who critiqued it). Rather than linking nature to women in an 'essentialist' way, we can profitably look at

15 These are excellent examples of the intersection of gender with other social modes of classification. Higher status men are also likely to have norms that constrain their behaviour. I remember from my childhood in Turkey, for instance, how much overt social pressure was placed on my father as a 'higher status man' whenever he opted to engage in any physically challenging work himself. Maureen Reed has observed that in Canada input from 'men who do not conform to particular forms of masculinity (either logger or boardroom guy or scientist) often get dismissed' (pers. comm.; or see Reed 2010). 
women's (and men's!) varying perceptions, and build on those that lead toward sustainable and equitable use, forest protection and holistic views of people and forests. Many writers have noted women's common knowledge of and interest in their environment (discussed in more depth below under micro scale). Such knowledge often exists and is more likely to have been ignored than men's knowledge. Forest managers can benefit from exploring existing emotional and cognitive links to nature, whether those of local men or women.

One intriguing and recurring pattern involves women, when pushed to the limit, using nudity in protest. Stevens (2006) writes, for instance, of the women of the Niger Delta:

\footnotetext{
'A mature woman's intentional exposure of her vagina is an extreme desperate act, threatened only when she feels that her most basic rights and obligations, ... her very dignity as a woman are endangered, and other methods of persuasion are realised as ineffectual and she has little to lose. To engage in this act of desperation by herself is extremely risky for a single woman; when many women assemble and make the threat collectively, their individuality as social people is irrelevant, and the amassed power of their femininity is absolutely awesome and terrifying.'
}

This is not an isolated example. Diabate (2011) provides a literary analysis of women's 'genital power' in West Africa generally (also discussed in Federici 2011). Colfer (2011) found examples of women exposing their breasts in fairly successful political protest - relating to land and forests - in Brazil, Zimbabwe and Indonesia.

Formal religion-The world's major religionsChristianity, Islam, Hinduism-often reinforce (or are the source of) ideas about female inferiority. Islamic purdah can constrain women's involvement with natural resources (e.g. Meinzen-Dick et al. 2012, on northern [patrilineal] Ghana). Andaya (2006) traces the arrival and effects of Theravada Buddhism, Islam and Christianity into Southeast Asia, where women had been centrally important in indigenous spirit-oriented religions. She concludes, somewhat optimistically, that '...though references to female spiritual and intellectual inferiority were persistent and pervasive, these [newly arriving] traditions ${ }^{16}$ were always amenable to alternative interpretations, and it would be misleading to assert an unambiguous narrative of declining female status.'

Some, including both Andaya (2006) and (Scott 2009), have de-emphasised the gender impacts of formal religion in Southeast Asia, particularly among upland (as opposed to lowland) contextsregardless of specific religion. Scott suggests that for many forest dwellers (in Southeast Asian uplands), ${ }^{17}$ a variety of civilisational effects may be less evident locally. 'This often inaccessible terrain meant upland populations were less susceptible to domination by lowland cultures informed by political-religious assumptions about female subordination' (Andaya 2006).

The degree to which a Great Tradition can be modified by locals is evident in West Sumatra; there, an Islamic tradition recognised as unusually strong throughout Indonesia is combined with matrilineality-a very different combination than one finds in the Middle East, for instance.

Modernity-Narratives of modernity represent another globalised trend with varying effects on the ground $;^{18}$ Arora-Jonsson (2013) notes, as does Pigg (1996) before her, the inherent links between the modernity narrative and the notion of 'tradition'the two notions are oppositional; each implies the other as its opposite.

16 As Pigg (1996) warns us, 'In development discourse, the word "traditional" always signals a world of shared and unquestioned beliefs. This is the realm of habit, rather than reason' (p. 178) —a belief she shows to be misleading.

17 Colfer et al. (2011) argued for a wider geographic relevance of these observations, based on research on people and landscapes in Cameroon, Indonesia, Laos and Madagascar (with the altitudinal situation in Madagascar reversed: those in power were in the uplands, the marginalised groups were in the lowlands). The situation Scott described for Southeast Asia did not seem to apply in Tanzania.

18 Melissa Leach, in a review of a draft of this paper, noted that an anthropology of globalisation would emphasise plural regional modernities, not a homogenising global trend.' I agree that anthropologists see the pluralities, but I question the degree to which others do. 
Educated Nepali women, considering themselves 'modern', rejected marginalising traditions (Nightingale 2011); Leve (2007) writes of women's active involvement in Nepal's Maoist war. These Nepali women explicitly linked education and modernity with more equality and greater opportunities. On the down side, the 'concealment, duplicity and collusion' of the Chinese government's linking of women's liberation to governmental concerns about modernity (in a locally male-dominated context), had adverse impacts on women's reproductive health (Yen 2009). Elmhirst (2011) examines Indonesian governmental notions of appropriate forms of marriage (which she calls the 'heteronormative conjugal norm'). These are clearly linked both to modernity and to approved land and forest uses (not, for instance, shifting cultivation).

In these multi-scale efforts to improve people's conditions and equity, we face a recurring dilemma: is it more effective to try to include women by fitting into existing patterns? Or should we attack the existing inequitable social, cultural (and power) structures head-on (as argued by Mutimukuru-Maravanyika 2010)? Although building on existing practice is usually more efficient in the short run, we are likely to reinforce existing gender stereotypes. The latter, more confrontational course can be dangerous, figuratively and sometimes concretely; and it raises ethical questions relating to cultural relativityquestions of cultural cohesion and people's rights to determine their own rates and directions of change.

There are no easy answers when we see the clash between global efforts to increase equity and valued but inequitable local customs. Meola (2012), for instance, though valuing many of the successes of the Amazonian conservation project she examined, questioned the desirability of some of the family changes she saw. Women who went to work sometimes had to leave young children unattended, spend long periods away from home and absent themselves from their customary networks. Boyd (2009) recognised the positive contributions of the climate mitigation project she examined in Bolivia (health care, education and income-generating components for women), but fretted these projects addressed practical, rather than the more important and long-lasting, strategic gender needs of empowerment (a practical preoccupation also noted by Djoudi and Brockhaus 2011, in Mali). Real progress in strengthening women's voices, access to resources and general life conditions will require complementing the practical with serious attention to the strategic (also noted by AroraJonsson 2013).

As we move from the macro to the meso scale, we must keep the interactions among scales in mind: to what degree are local and meso processes affecting these broader issues? Who is championing and who is resisting the various changes underway? Global human and environmental diversity dictate that much such work will have to happen at meso and micro scales.

\subsection{Meso scale}

What I am calling the meso scale is actually a variety of levels_-from national to multi-village or landscape. Its influence on individual women, men and forests is likely to increase as scale narrows, becoming most powerful closest to village and individual levels. I focus below on four broad categories of concern at these levels: land/forest ownership, norms of behaviour, educational opportunities and the intrusion of cash economies. Such issues can be relevant, as noted initially, at all levels; but the meso scale is likely to be a particularly fruitful context for addressing them.

\subsubsection{Lands, forest and ownership}

Interplay between formal systems of land tenure and traditional ones (Marfo et al. 2010) is ubiquitous in tropical forests. Key issues include gendered access to resources (land, forest, nontimber forest products); security thereof; and kinship-related inheritance and residence patterns.

Access to resources-In many forests, tenure derives at some level from the 'axe right': the premise that he who cuts the forest-and it is almost always a man who wields the axe or chainsaw_gains rights to it (see Diaw 2005, on this forest principle in Africa; Fortmann and Bruce 1988, for the European version, called 'assartment').

But the complexity of this issue defies simple treatment. There are often multiple rationales for 
such access (e.g. customary rights vs. statutory rights). Men and women may have access rights that differ by locale, by season, by crop; access may differ between land and trees. Different strategies may be recognised for establishing ownership or control of resources (e.g. labour, group membership, network connections). These divergent elements often yield uncertainties and opportunities for power plays in which women are likely to lose out.

Recently, evidence has surfaced linking women and reforestation efforts: in El Salvador, rather than cutting down distant trees to establish more secure ownership — as happens in many contexts-women (many of whose men were absent) established ownership by planting trees in agroforests and home gardens close to home (Kelly 2009). They thereby demonstrated the 'active use' required by the government.

There are parts of the world where women's access to land has been no more problematic than men's (e.g. the Malagasy described by Gezon 2012; the Kenyah in Borneo, Colfer 2009; the Khmu in northeast Laos, Michelle Roberts, pers. comm.). But these represent the minority. Women's access to land in India is widely recognised as inequitable: Naga women of north India do not own land generally (Cairns 2007); Jassal (2012) found that women's lack of rights to land, a touchy subject where she worked, also in northern India, resulted in serious disadvantages for women's status and work opportunities. See Koopman and Faye (2012) for an historically informed examination of this issue in several countries in Africa.

Security of access-In many parts of Africa, women's rights to land have traditionally come through men. When marriages fail or bride prices are not paid, women can be left landless. This insecurity has been exacerbated in recent years with the move toward land privatisation and 'structural adjustment conditionalities' (see Federici's 2011 nuanced discussion of the adverse implications for women in East and southern Africa; or Koopman and Faye 2012). Richards (2006) notes particularly the vulnerability of widows and divorcées to loss of access to land in war-torn Sierra Leone and Liberia (also noted by Agarwal 2010, for India and Nepal; Goebel 2003, for Zimbabwe; Pandolfelli et al. 2007 and Gillespie 2008, with regard to HIV/ AIDS widows' susceptibility to land grabbing). El Salvadoran women whose husbands are away earning money may suffer similar vulnerability (Kelly 2009). In Ethiopia, even when women own assets, men may control them (Mabsout and Van Staveren 2010); also reported in Sumatra by Suyanto et al. (2001).

Social, economic and ecological change can also affect ownership. The lack of secure ownership of land increases women's vulnerability to climate change crises (see Ahmed and Fajber's 2009 Gujarat findings) and reduces their ability to participate in collective action (Pandolfelli et al. 2007). Quisumbing et al. (2001) examined two matrilineal systems: Ghanaian women gained land rights by helping their husbands on newly formed cocoa farms, whereas Sumatran women lost rights as men became more involved in agroforestry (thereby competing with women's traditional dominance in paddy rice cultivation). A parallel shift was seen in the Gambia-from female dominance of gardens to male dominance of agroforestry (Schroeder 1999). But the issue is not simply a 'woman's problem': Barker and Ricardo (2006) provide examples from various countries in sub-Saharan Africa of the key roles that access to land plays in men's life cycles-in their ability to 'achieve' manhood-and their difficulties due to civil unrest, warfare, refugee status and/or the dominance of older men.

Kinship and inheritance rules—-Rights and security of access and inheritance rules are mediated by the prevalent kinship system, which typically exerts a meso-level influence. ${ }^{19}$ Whether a group is patrilineal, matrilineal or bilateral can make a big difference in women's access to land. In patrilineal groups, women formally may have no direct access to land. But they may gain access from a variety of sources: from their husbands (most common); via mothers-in-law (as among the Luo of Kenya, Shipton 2007); by using marginal lands (found by many, since Rocheleau's (1991) initial discussion based on findings from Machakos District, Kenya) $;{ }^{20}$ or by enlisting outsiders' help

19 See Jiggins' (1994) outline of seven key, traditional, cultural principles at work in Nigeria. One of these emphasises how 'Access to and control over economic resources and benefits were vested in membership rights [in a lineage], not ownership rights' (p. 185).

20 Rocheleau refers to such 'off-farm lands' as 'roadsides (public land), stream banks and riversides (a combination of public and private property), hillslope woodlands (mostly private land), the dry forest across the river (national government land) and most importantly, the grazing 
to combat inequitable land holding traditions (cf. Nemarundwe 2005, on women's gardening efforts in Chivi, Zimbabwe). In many places, land and tree tenure are different 'animals'. Women may be able to claim tree ownership on others' land, though they may not be able to plant trees, due to the long-term nature of such crops and resulting anticipated conflicting claims.

Matrilineal systems, despite the continued dominance of men in much decision making (see e.g. Noerdin 2002), provide a more hospitable context for women's access to lands. In the hinterlands of West Sumatra and in Jambi, among the Minangkabau, land ownership formally rests with matrilineal clans, and women have straightforward and secure access to paddy rice fields (Colfer et al. 1988); however, Suyanto et al. (2001) argue that husbands have a strong voice in agricultural decision making. ${ }^{21}$ Forest lands that husbands clear for swiddens (and subsequent rubber orchards) belong to the husband and can be inherited by the man's children (also noted in Ghana where men cleared forest for cocoa). Bourdier (in press) recounts women's unusual access and security of tenure among the matrilineal Tampuan of Cambodia. A less equitable situation exists among the matrilineal Akan of Ghana, but one in which Quisumbing et al. (2004) see women's access to land as increasing with the adoption of cocoa-by creating incentives for husbands to give their wives and children land'. ${ }^{22}$

Bilateral systems are often the most womanfriendly (cf. many such systems in Southeast Asia), though Laderman (1996) notes the bilateral Malay women of Trengganu rarely own land). Among the Kodi of Indonesia's eastern island

lands, woodlands, fencerows and gullies of other farmers (private holdings, small medium, and large)' (1996, p. 162). For a more recent discussion of this phenomenon, see (Federici 2011).

21 One wonders if the differing impressions/emphases of myself (a woman) and Suyanto (a man) may also reflect differing perceptions among local men and women (as Behrman et al. 2012 found-Ugandan couples studied did not necessarily agree about what they jointly owned).

22 I remain uncertain why these authors consider fathers giving to their children inherently better than uncles giving to nephews (see MacLean 2010, for a nice comparison of how these Akan systems function in Ghana and Côte d'Ivoire), though both analyses note that when a man dies and his matriclan reclaims his land, his wife and children may be left homeless and destitute. of Sumba, patriclans are key in inheritance and land ownership, but matriclans have parallel but different functions (Fowler in press). Patrilocality further strengthens men's position vis-à-vis women's with regard to land, though Fowler sees day to day gender relations as relatively egalitarian.

Another moderating influence, which has a long history of attention in gender studies, is household headship, with female-headed households seen as generally poorer than male-headed households. Recent work has become more nuanced. Jacobs et al. (2011), for instance, found that whereas female heads of household controlled nearly as many assets as male heads of households in rural Kwa Dube, South Africa, women in all-women households controlled far fewer, and women in male-headed households had the least of all. These authors found that women heads and women who were divorced, widowed, separated or co-habiting unmarried had comparatively stronger 'asset rights' - yet another indication of the inappropriateness of seeing 'women' as an undifferentiated mass. A parallel study, also coordinated by Jacobs, in Uganda, noted advantages for women heads in ownership (though not necessarily in decision making authority), and disadvantages for wives and partners in maleheaded households. An interesting finding was the different responses of men and women about joint ownership (reported in Behrman et al. 2012b, who also provide an excellent discussion of how to assess assets, as bundles of rights). Deere $\mathrm{et} \mathrm{al}$. (2010), discussed in the previous section, note how women's ownership disadvantage has been systematically exaggerated by looking only at ownership of female household heads.

\subsubsection{Norms about gender roles, age}

Notions about appropriate behaviour for men and women may extend broadly throughout a region, caste, class and/or ethnic group. I first outline some of the different perspectives extant about this issue, in terms of ideal gender roles. Behavioural ramifications that flow from these ideas include mobility, voice, family planning/health and treatment of the elderly. The huge diversity of views, from region to region, group to group, and within communities means that what is presented here is simply illustrative. 
Gender ideals - Writing about such ideals one is in danger of reinforcing essentialist stereotypes; yet there is little doubt that such notions, in fact such stereotypes, cultural as they are, have real impacts in the world's forests.

'Hegemonic masculinity'-as portrayed in gender studies on men-also manifests itself at the meso level, varying by group. The historical importance of warfare, including headhunting, and the related expectation of men to protect women (discussed below), are seen as key ideals for men among the Naga of northern India (Cairns 2007). Men's protective, guarding roles are deemed partly responsible for Naga women's dominance in the agricultural labour force. In Kenya and Tanzania, the traditional ideal male role involved becoming a polygynous warrior, herder, politico, with strong values on self control, dignity and procreation (Silberschmidt 2001). Silverschmidt attributes men's sexual promiscuity and domestic violence as attempts to reassert manhood in this changed context where they are disempowered, unable to fulfil traditional expectations. In Cameroon, Veuthey and Gerber (2010) stress the importance of building a house, clearing a field, hunting and (traditionally) warfare as central to men's roles. Such expectations constrain men, just as norms of female behaviour limit and condition women's lives.

Among other groups, hegemonic masculinity does not appear to be a factor. ${ }^{23}$ In the Central African Republic, Noss and Hewlett's (2001) study of Aka (pygmy) women's hunting stresses the group's egalitarian ideology and practices, with men and women sharing 'subsistence, child care, leisure and ritual activities' (something also found among Iban and Kenyah Dayaks of Borneo-despite their headhunting histories; see also Tsing [1990; 1993] on the Meratus of Borneo). In Sumba, in eastern Indonesia, people see men as having to exert effort to attain masculine status. Men are seen ideally as 'active, mobile and transformative', while women's agency is 'stable, unmoving and substantive' - and nearly automatic — coming with childbirth (Fowler in press).

No single phrase has been as widely used to describe notions of the ideal woman as has 'hegemonic masculinity' to describe the ideal man. Women in Kenya and Tanzania are seen as much more hardworking, entrepreneurial and inventive-they 'have a strength that men do not have' (Silberschmidt 2001). See also AmuyunzuNyamongo and Francis (2006), on Kenya, where women took on some of men's traditional responsibilities, resulting in tensions within families and ultimately to domestic violence.

In northern India, women express their ideals in words and song. They emphasise submission, maintenance of the patrilineage's honour, purity and obedience to husband and mother-in-law (Jassal 2012).

The changing nature of contexts and the impacts on broad cultural notions about gender and age are clear in the writings of Giles-Vernick (2002). She emphasises the sense of cultural loss associated with elderly men's reduction of authority among the forest-dwelling Mpiemu of the Central African Republic. For a historical perspective on changing gender ideals in Southeast Asia, see Andaya (2006).

Among some groups, a long history of male migration accompanies idealised working strengths of women (e.g. in north India, Jassal 2012; among the Kenyah of Borneo, Colfer 1985). Naga women's pride in their own industriousness is seen as a complement to men's idealised, traditional function as fierce warriors (Cairns 2007).

Among the Lahu, a large ethnic group in southern China, there is an unusual degree of shared responsibility and work between husband and wife-including shared conduct of a pregnancy and childcare-in the Lahu ideal of marriage (Du 2000); cf. Noss and Hewlett 2001, on the Aka). $\mathrm{Du}$, like those she studied, contrasts these Lahu ideals with those of the neighbouring, less genderequitable, patrilineal Han.

Elmhirst (2011) links the Indonesian government's interest in controlling forests and their use, with pressure and incentives to conform to what she calls gendered and 'hetero-normative ideologies'. In this vision, '...the nuclear family/ household is a building block of the nation, with the male household head seen as the point of contact between state and people'. The Soeharto government's expectation that women would be most fundamentally pendamping suami (at 
their husband's side) supports this view (OeyGardiner 2002). Oey-Gardiner emphasised a slight improvement since 1993, when 'women were declared mitra sejajar (equal partners) in development, but remained constrained by maleimposed concepts of women's kodrat (nature), harkat (dignity) and martabat (status)'. ${ }^{24}$

Some writers have included 'protector' as part of the masculine ideal (e.g. Moore 2009); others note this same concern with dismay: Noerdin (2002) complains that in West Sumatra, ' $(t)$ he customs of the Minangkabau stipulate that women should be under the supervision and protection of a man'. ${ }^{25}$ Similarly in El Salvador, men are legally required to 'protect' their wives (while women owe them obedience, Kelly 2009). Among the egalitarian Lahu (southwest China), husbands are expected to protect their wife and child from evil spirits during the post partum period of 'mother roasting' ( Du 2000). 'Protection' can be used as an excuse to limit women's involvement in activities perceived to be subversive of existing authority structures (see Jassal 2012, on north India).

Mobility-The frequently noted constraints on women's travel represent potent interference with their involvement in conventional forest management (see e.g. Brown 2011, Lewark et al. 2011, Mwangi et al. 2011, Purnomo et al. 2011, Shackleton et al. 2011, or its inclusion in the SIGI indicator on 'civil liberties', OECD 2010. ${ }^{26}$ Such constraint can result in differences in women's and men's environmental knowledge-near home and far ranging, respectively-in the Amazonian Mamirauá Sustainable Development Reserve; and the conflicts-both internal/emotional and with their families — of women who took paid, project jobs that required them to travel (Meola 2012). Among the Kodi of Sumba, in eastern Indonesia, Fowler (in press) also emphasised

24 Colfer also encountered this official concern with kodrat, as we collaboratively planned a project in Jambi, Sumatra. We hoped to design collaboratively more equitable involvement of men and women in forest management and land use planning (Komarudin et al. 2011).

25 A gender analysis among the Tolaki of SE Sulawesi reveals the ideal protective role of older siblings to younger ones, with younger siblings owing respect to their elders. Gender is irrelevant to this opposition (Bergink 1987).

26 In the SIGI framework, one of two variables on 'civil liberties' is phrased thusly: 'Freedom of movement indicates the extent to which women are free to move outside the home.' (p. 16). the lesser mobility of women vis-à-vis men and its implications for their day to day experience. South Asia is well known for ' ...the constraints on women's physical mobility due to domestic responsibilities, security considerations and (in some communities) female seclusion norms....' (Agarwal 2010, see also Basu 2003, Torri 2010).

Others have noted the greater involvement of women in change efforts when meetings are scheduled close to home (e.g. Sen and An 2006, on Vietnam, Cronkleton 2005, on Amazonian Bolivia). Still others have noted the greater mobility of more educated women in Nepal (Nightingale 2003, see Tambiah 2003, on the political and cultural constraints to women's mobility Nepal, Pakistan). Mobility can be important for women's access to markets in some areas (Tripathi et al. 2012). Behrmann et al. (2012b) found that NGOs can play a positive role in enhancing women's freedom to travel.

Whereas women's reduced mobility seems quite widespread globally, there is huge variation in the norms associated with gendered forest involvement, both between and within groups. Some of those highlighted in the literature include:

- High-status men in West Nepal do not work in the forest: to cut timber is to be a dalit (low caste) man, and to do other forest work is to be a woman (Nightingale 2011).

- Purdah in Islamic areas can discourage women from forest involvement (cf. Gupte (2004) for Rajasthan, India; Meinzen-Dick et al. 2012, for northern Ghana), as can concerns about status (examples noted earlier from India, Indonesia and Mali).

- In Southeast Madagascar, it is taboo for women to go alone into the forest (Lyon and Hardesty 2012).

- Torri (2010) describes the double bind of young Indian women whose duty it is to provide the family with firewood, but who thereby must contravene rules determined by male elders forbidding them to do so in nearby forests.

- The monopoly of Bantu men in Cameroon on hunting and forest clearing results in less legitimacy of women's claims on the valuable moabi tree (Veuthey and Gerber 2010). Bantu women throughout Central Africa are actively involved, however, in forest-based farming (swiddens) —as are women in most forest-based swidden systems of the world. 
Voice-Norms vary in the degree to which groups discourage women from speaking up in public, which can have particularly adverse effects on their involvement in formal forest management. Aka women openly and freely involve themselves in community decision making (including questioning men's authority) in the Central African Republic (Noss and Hewlett 2001); among Khmu women in northeastern Lao PDR, shyness is rare, though the courage to speak up strengthens with age (Roberts in press). Although the Kenyah Dayak women of Borneo tend to sit in the background at community meetings, rarely speaking up publicly, there are numerous opportunities for them to make their views known in smaller domestic and neighbourhood gatherings (Colfer 2009). McDougall and her ACM team in Nepal found that a nested organisation of forest user groups by neighbourhood rather than all-village meetings significantly increased women's voice in forest-related decision making (e.g. McDougall et al. unpublished). The women in forested areas near Gokwe, Zimbabwe (ethnically Shangwe, Ndebele and Shona primarily) prefer acting behind-the-scenes (Sithole 2005); and AroraJonsson (2009) examines the lack of interactional fit between women's concerns and preferred ways of interacting vs. the formal ones employed in conventional, male-organised forest management in Sweden and India (see also Reed 2003, who makes a similar point about Canadian forestry). Arora-Jonsson argues forcefully and convincingly for the value of granting separate spaces for women to group according to their own interests and organisational preferences. A comparison between India's more traditional region of Rajasthan and the more 'progressive' Maharashtra found women's voices to be much more clearly and publicly expressed about community forestry in the latter than in the former (Gupte 2004).

Outside groups have typically called for stronger voices for women in forest management and community decision making (e.g. World Bank 2009, UN-REDD Programme 2011, High Level Panel of Experts 2011); and individual researchers have addressed the issue at the meso level (e.g. Bose 2011 and Agarwal 2010, in India; Shanley et al. 2011, in Brazil; Shackleton et al. 2011, for Burkina Faso, Ethiopia and Zambia). Pandolfelli et al. (2007) highlight both constraints and avenues to greater voice in various locales.
Some researchers have described mechanisms for strengthening women's voices (see e.g. Kusumanto et al. 2005, or Permatasari 2007, in Jambi, Sumatra; McDougall et al. 2009, in Nepal). Meola (2012) describes the process of change as women, initially shy, became comfortable speaking up in Mamirauá Reserve management (Brazil). Conventional attempts to involve women in formal decision making bodies have often encountered barriers: in Trengganu, Malaysia, one woman's own reluctance (and refusal) to join a decision making body was reinforced by the praise of other women for her decision (Laderman 1996). Torri (2010) and Ahmed and Fajber (2009) encountered similar barriers in India, in Rajasthan and Gujarat, respectively.

Family planning and health-Attitudes toward family planning and health can also have mesolevel effects. On the one hand, effective access to family planning can liberate women for greater involvement in forest-related activities, as seems to have been the case in Kalimantan (see Colfer et al. 2008, for a stylised version of systemic interrelationships of this kind, using 'causal loop diagrams'). But strong pro natalist cultural pressures, such as are found among the Luo (Shipton 2007), for instance, can undermine such tendencies. In many forested areas, one finds women anxious for access to family planning (often more so than men): Meola (2012) found such interest on the Amazon; Torri (2012) describes the value Indian women in Tamil Nadu attached to contraceptive plants; Hull and Adioetomo (2002) recount the very successful experience of Indonesia's family planning programme. The utility of such access, both for the health of forests and of people, is well established.

Concerns about family planning and population within forests lead naturally to women's health concerns in forests (Wan et al. 2011). Allotey et al. (2008) summarise the ways in which women's health has been inequitably attended in forests. Other researchers have also found issues ranging from the excessive exposure of women to

- air pollution from cookstoves (Naeher et al. 2007).

- HIV/AIDS (e.g. Silberschmidt 2001 on the Gusii, or Shipton 2007 on the Luo, Kenya).

- Extra vulnerability under flooding conditions, due to women's simple inability to swim (a modesty consideration) in Gujarat, India (Ahmed and Fajber 2009). 
Women also have special interests in maintaining health because of their common role as primary caretakers of ill family members. In many areas, women are those who know about medicinal plants (cf. Leaman 1996, for the Kenyah of Kalimantan; Anonymous 2012a, on the Adi of the eastern Himalayas, India; Voeks 2007, Brazil).

Age- The study of the Adi reminds us of the implications of age, linked with gender. Andaya (2006) writes of the 'liminal state' of elderly Southeast Asian women, with both positive and negative connotations. The latter include their links with witchcraft (e.g. Fowler in press, on the Kodi of Sumba) and/or other links with the spirit world, which can be positive or negative. Concerns about witchcraft are less gendered in many parts of Africa, though Gezon (2012) notes the prevalence of a 'deuxième bureau' [a mistress] for men in Madagascar, and mutual fears by wife and mistress of being bewitched, each by the other. Federici (2011) examines the growing incidence of such accusations in many countries in Africa, which she links to land conflicts, economic hardships, devastating health conditions and more.

In Rajasthan, widows may encounter serious discrimination (Torri 2010); similarly divorcées in Trengganu, Malaysia (Laderman 1996). Among the Mende (Sierra Leone), an older wife in a polygynous household has a legitimate, advantaged, customary status, with younger wives working harder and having less free time. Sometimes, however, a younger, 'beloved wife' can upset this expectation (Leach 1992). Among other groups, such as some in Ethiopia, older women have a lower bargaining position within the household. Mabsout and Van Staveren (2010) conclude, based on a thorough quantitative study in Ethiopia, that '...women living in ethnic groups with very unequal gender norms do not experience an increase in their decision making power when they get older, have more education or contribute equally to household expenditures'.

\subsubsection{Educational opportunities}

Literacy, improving education access and loss of indigenous knowledge are key issues here.

Literacy-One of the most central issues related to education is the relevance of literacy for involvement in the formal management of forested areas.

In parts of Latin America and the Caribbean, as noted above, it is the men who suffer from lower literacy rates and lower educational achievement. The women of Mamirauá (Brazilian Amazon) were more likely than men to be literate, a feature that granted them greater access to wage labour in the local conservation project (Meola 2012). But for most of the world, women's illiteracy rates are significantly higher.

In many contexts, illiteracy keeps women out of the forest information loop (World Bank 2009). Illiteracy was a major impediment to women's meaningful involvement in decisions about forest use that directly (and adversely) affected them in a protected area in India (Torri 2010; see also Agarwal 2010). Torri concluded that '(i) improving literacy of women is essential to promote their participation in village institutions and empower them'-a view echoed by WOCAN (2012) in Nepal, D'Agnes and Margoluis (2007) in Madagascar, and Yen (2009) in China, Jaquette (2010) for indigenous groups in South America, among many others. Adult literacy programmes in Nepal have had genuinely revolutionary impacts (Leve 2007). Illiteracy can even preclude women's involvement as respondents in surveys about them (Quisumbing et al. 2001, in Ghana). ${ }^{27}$

Women's illiteracy has kept them out of REDD+ policy-making circles in Nepal (WOCAN 2012), out of governance more generally in South Asia (Nussbaum 2003), out of forest users' policymaking in communities in Rajasthan (Torri 2010). Lachapelle et al. (2004) stress the disempowering features (both personal/internal and societal/ external) of illiteracy and low educational levels for women and other marginalised groups in Nepal's community forest groups. Literacy rates among female NTFP traders were higher than average when Ruiz Pérez et al. (2002) conducted their research in Cameroon: $87 \%$ of traders are literate vs. $46 \%$ national literacy average for women. ${ }^{28}$

27 See Kothari (2003) for an example of persistence in seeking input from illiterate women that paid off well, in Ecuador; or Dangol's (2005) adaptive collaborative management experience in Nepal.

28 The SIGI now places Cameroonian women overall fairly close to men in adult literacy (60\% to $77 \%$, respectively). 
Illiteracy also interferes with women's access to policy making about reproduction in China (Yen 2009), involvement in a family planning programme in Madagascar (D'Agnes and Margoluis 2007), secure land tenure in El Salvador (Kelly 2009)—all indirectly related to women's capacity to be involved in forest management activities.

Illiteracy levels also tend to be higher and educational achievements lower among indigenous groups - often located in forested regions - with indigenous women routinely representing the extremes. World Bank (2011), for instance, notes that ' $(\mathrm{t})$ he illiteracy rate among indigenous women in Guatemala stands at $60 \%, 20$ points above indigenous men and twice the rate of non-indigenous women'. Another World Bank synthesis (2009) links women's illiteracy, lack of market information and problems of transportproblems found also by Shackleton et al.'s (2011) meso-level study of NTFP trade in Burkina Faso, Ethiopia and Zambia.

Improving educational access-There are, however, encouraging signs: '.. in a third of developing countries, there are more girls in school than boys' (World Bank 2011); and there is growing recognition of the positive ripple effects of enhancing women's education (Behrman $e t$ al. 2012b). These same authors note that

\footnotetext{
'Increasing women's control over assets, mainly land, physical and financial assets, has been shown to have positive effects on a number of important development outcomes for the household, including food security, child nutrition and education, as well as women's own well being'.
}

There are a variety of extant avenues to improving female literacy: Leve (2007) attributed improvements in women's literacy and 'conscientisation' in Nepal to their involvement in the Maoist insurgency. Tripathi et al. (2012) describe an initiative in Ethiopia in which women form beekeeping groups: besides strengthening their knowledge of and involvement in beekeeping, these groups organised themselves for adult literacy.

Among some groups, girls show more interest in schooling than boys (the island nations of the
Caribbean, the Kenyah of Indonesian Borneo [Colfer 2009], the Naga of India [Cairns 2007]). Although Akan girls in the cocoa growing areas of Ghana remain educationally disadvantaged compared to boys, their educational levels are improving; a related study showed higher levels of female education in Sumatra, though still lower than men's (Quisumbing et al. 2004).

In other areas, the lower educational achievements of women are interfering with their involvement in a variety of natural resource-related development efforts. Women in the uplands of Vietnam have lower educational levels than local men; as a result, they receive less training and extension than men, despite women's dominance in provision of agricultural labour (see Sen and An's 2006 account of efforts to redress this imbalance via action research in upland communities; or Vernooy 2006). This inequitable pattern is not unusual. Torri (2010) reports the experience of Indian women, who, as part of their involvement in community-based conservation initiatives, were able to obtain training and other educational opportunities that allowed them to improve living conditions (as well as contributing to the conservation concerns). In another report, Torri (2012) found that Indian women, particularly those from 'scheduled castes' found the creation of home gardens and the related training they received increased their social status at home and in their communities.

The need for young female labour at home is a recurring impediment to girls' education. Malay girls in Trengganu are taken out of school after sixth grade, as their mothers need their help at home (Laderman 1996); rural Nepali girls feel serious conflicts between their domestic duties and access to education (Leve 2007); many authors have noted the need for fuel wood interfering with girls' educations (World Bank 2009). Malagasy women's lower educational attainments contribute to their involvement in cultivation of the peri-legal drug, khat (Gezon 2012).

Loss of indigenous knowledge-Less frequently emphasised in the literature, though particularly relevant in forests, is a 'down side' to such formal education: of indigenous knowledge a variety of losses - of elderly women's indigenous forest knowledge in India, (Anonymous 2012a); of gendered indigenous knowledge of forestry and 
soil management in Cameroon (Russell and Tchamou 2001); of Arawakan women's knowledge related to agriculture and biodiversity in the northwestern Amazon (Venezuela), as people have been drawn into a society of jobs (and now eroding government welfare, Hoffman 2003).

\subsubsection{Cash related changes benefitting one sex or the other}

Cash from timber sales, the forest product with the longest and most male-dominated history throughout the world, has rarely been available to women. Men have traditionally staffed formal timber management organisations; men have formed most participants, especially most leaders, in most community forest management committees; and men are those who wield the chainsaw and thus tend to have a greater say in use of resulting income from timber sales, at the family level.

Although areas where cash is a recently introduced phenomenon have become rare, there still remain in many forests, areas where a subsistence economy has dominated. ${ }^{29}$ In some areas, subsistence dominance has meant that men and women could have fairly equal access to a whole range of products (cf. Colfer 2009, on the Kenyah of Borneo). Andaya's (2006) gendered history of Southeast Asia discusses men's takeover of indigo, pepper and cloth. She concludes that '... commercialisation inevitably advantaged men's access to financial resources' (as does Fedirici 2004, globally). Here I focus on women's typically limited access to cash, their external invisibility and consequent adverse ${ }^{30}$ effects, and women's occasional income successes, concluding with some regional differences.

Limited access to cash-The remaining systems where subsistence has been the primary component of local economies are changing quickly_often

29 Dove (2011) describes the historical and adaptive shifts in the balance between a subsistence and cash emphasis among smallholders in Southeast Asia—though his treatment of gender dimensions is perfunctory.

30 Though Arora-Jonsson (2013) makes a good theoretical argument for the male-gendered nature of this interpretation of such female invisibility. Her argument suggests that we should be building on women's less formal, less public, more invisible grouping mechanisms in forest management. fomenting corresponding changes in gender roles, status and interests. The adverse implications of men's inabilities to fulfil the provider role ${ }^{31}$ for their status in eastern Africa have already been discussed. But there are perhaps stronger countervailing forces that limit women's access to cash. Ruiz Pérez et al. (2002) found, for instance, that $89 \%$ of 1100 estimated traders operating in 25 NTFP markets throughout Cameroon were women, and that women had been involved in the trade for a longer time than men. Yet these male, relative newcomers to NTFP trade (prompted partially by the economic crisis then underway in Cameroon) had average sales value 7.6 times as large as that of female traders. ${ }^{32}$ Cameroonian women have traditionally been responsible for food production for the family. But Brown and Lapuyade (2001) found that men have taken on some of these responsibilities, as well as discretionary control over use of resulting funds (partially again in response to the economic crisis). Women have thus lost control over surpluses they had used for the basic welfare of all household members, including their husbands. All in all, these men saw life as easier now than a few decades ago, whereas women saw it as more difficult. ${ }^{33}$

\section{External invisibility of women-Women's} involvement in NTFP value chains, ${ }^{34}$ whether these are considered to be within men's or women's cultural bailiwicks, tends to be externally invisible. Shackleton et al. (2011) analysed NTFP value chains in Burkina Faso, Ethiopia and Zambia. In their research, the income consequences for women are delineated, men's dominance of export crops clarified and suggestions for enhancing equity are provided. Veuthey and Gerber (2010) explore the gender implications of the valued timber species, moabi, in southern Cameroon. Women there seek to conserve the tree, both for their own use of its

31 Though Silberschmidt (2001) dates the concern that men in East Africa serve a provider function to the 1940s and ' 50 s.

32 These authors also found women's enterprises to be as efficient as men's.

33 Whereas writers on East Africa have found women to be more creative in dealing with economic crisis, Brown and Lapuyade (2001) concluded that Cameroonian women had been less successful than men at diversifying sources of income under such conditions.

34 These authors also note the exception of shea butter in West Africa-a product clearly in women's hands (discussed thoroughly and historically by Chalfin 2004). 
many products and in light of their exclusion from income benefits that accrue from its being logged for export.

Into the distinctly patriarchal Meru District of Kenya, Dolan (2001) looks thoroughly at the intrusion of a horticultural export crop (French beans). Men there have been able to appropriate female land, labour and income. ${ }^{35}$ Dolan shows women's disadvantages linked to lack of land tenure and resulting lack of contractual opportunities. She examines women's maneuvering within cultural constraints to both retain their good names and subtly resist inequity; and she emphasises the adverse consequences of 'agricultural diversification initiatives based on a unitary model of the household decision making' for gender equity and capital formation. This example, though agricultural, highlights important issues relevant to people's interactions with forests and trees as well.

Similar results obtained in the Gambia, where men's and women's incomes represented separate streams within families. Schroeder (1999) documents how an external project to develop gardens advantaged women in a variety of ways (including income-wise), and was then superseded by another external project on agroforestry that returned the advantage to men economically. A garden project in the Bamana region of Mali disadvantaged women vis-à-vis men as it emphasised export crops, reduced biodiversity and food security, and dismissed women's knowledge (World Bank 2009, originally from Wooten 2003).

Women's income successes-We have also found examples, though fewer, of women gaining income advantages as economies change. Less educated Malagasy women were able to fashion economic advantage by filling a niche where literacy was irrelevant and by marketing the marginally legal drug, khat (Gezon 2012). Women in northern Ghana have continued to dominate the collection, processing and trade of shea butter, even as international markets have opened up. Chalfin (2004) looks historically and globally at the chequered career of this commodity, from the 'vantage point of the rural women whose livelihoods depended on shea processing and

35 Koopman and Faye (2012) look at similar, land-related issues in several African countries. marketing' (p. xiii; see also Wardell 2012). Lao Lum women of northeastern Laos responded enthusiastically and profitably to opportunities to weave cloths for tourists, with encouragement from their husbands (reported by Roberts in Colfer et al. in press; also seen in a women's project to market garden produce in India, Nakro and Kikhi 2006).

Regional differences-In Asia, the linking of men with cash crops, often reinforced by governmental attempts to encourage such crops (to reduce shifting cultivation and/or to enhance foreign exchange), is common (cf. the Karen of northern Thailand, Tazaki in press); Minangkabau and Melayu of central Sumatra, Colfer et al. 1989; Batak of Palawan, Philippines, Novellino in press). A similar pattern is clear in Africa, as discussed above.

Examples from Latin America suggest a quite different set of conditions. There, attention to credit availability, intra-familial life cycles and intra-household dynamics are key. One study examined forest communities in Peru and Brazil (Campbell et al. 2005). Over time, women in the Brazil case began spending more time in urban contexts (either as housewives or doing wage labour), while men took on more work in field and forest. In Peru, the men's involvement in agroforestry increased in response to male incomegenerating opportunities (logging was a main source of income). Peruvian colonist women, seen as more responsible at handling money, became involved in both support activities for logging and decisions to undertake this activity (deemed locally to be undesirable). Cronkleton's (2005) study also indicates both Bolivian women's involvement in household financial management and their lesser direct access to external sources of income.

In comparison to macro-scale factors, the meso scale is marked by considerably more diversity. Such diversity expands further as we move to the micro scale. One central take-home message- ever clearer as we move to the microscale-is the importance of examining carefully the varying factors and trends operating in any given context. Within the field of forestry, there is often inadequate recognition of the complexity represented by human systems; social systems may represent even more variety than do biological systems. 


\subsection{Micro scale}

It is at the micro scale, of course, that the most extreme variation exists; it is also the scale with the most power to affect people's behaviour-and thus, I argue, the scale at which we need to focus considerable attention, despite the inconvenience of its diversity. Within this scale, I have opted to examine five topics: i) gendered economic roles, ii) demographics, iii) valued domestic roles, iv) intra-household power dynamics and v) alternative paths for improving livelihoods. Each of these can, of course, also be examined at meso and macro scales.

\subsubsection{Gendered economic roles}

This section begins with a discussion of some varying views on the average physical differences in strength between men and women. It then shifts to the varied gendered involvement in food security, use of various field types, migration, climate change, NTFPs and livestock.

On physical strength-Although the physical similarities between men and women are far broader than the differences, there are some tasks, particularly in forests, for which men have a physical advantage. Even among quite egalitarian groups, like the Lahu of southern China (Du 2000) or the Kenyah of Borneo, people acknowledge and value the greater physical strength of (most) men (Colfer 1983). Physical strength can, on the other hand, be an indicator of low status in some contexts. Whereas Nightingale (2011), for instance, writes admiringly of the 'fitness, agility, strength and drive' required of male Dalit [a lower caste of] wood cutters in Nepal, local elites despise them; she also notes the pride local women feel in their ability to carry heavy head loads of fuel wood. Many women express pride in their ability to withstand the pains of childbirth. Different actors within the same context can value the same thing differently.

In northern India, Naga men refer to their own greater strength as a rationale for their claiming the valuable alder trees, the pollarding of which requires both extra strength and the ability to climb trees-a skill prohibited as 'immodest' for women. Cairns (2007) concludes that Naga men undertake the most physically demanding tasks and women, the most onerous. ${ }^{36}$ Across the globe in the Mamirauá Reserve (Amazonian Brazil), Meola (2012) notes local appreciation of men's strengths, specifically their ability to climb trees to secure special forest fruits, cut and burn fields, dig postholes, do heavy livestock work and fish.

Quisumbing et al. (2001) link women's physical difficulties clearing forest in Ghana and Sumatra to their greater likelihood to plant trees, as a strategy for claiming lands. Kelly (2009) also found this in villages in El Salvador, where she linked it to women's need to remain closer to home and to strengthening security of existing land claims. Quisumbing et al. (2004) also link Ghanaian men's dominance in cocoa production (vis-à-vis women's emphasis on food production) to the greater physical strength purportedly necessary for the former. There is no doubt, however, that cultural notions both define and expand on these physical differences, often exaggerating the abilities of one or the other gender and overattributing particular traits to men or women (thus 'naturalising' the social).

\section{Food security (practical and ritual} considerations)-More central to the concerns of this framework, however, is the frequency with which women's socially defined roles in agriculture are shown to be vital for food security. Cameroonian Bantu women's emphasis on, and responsibilities with regard to, food production and harvesting of foods from forests are clear (Russell and Tchamou 2001, Brown and Lapuyade 2001, Tiani et al. 2005, Veuthey and Gerber 2010). A comparison between western Ghana and Sumatra highlights women's food production responsibilities in both countries (Quisumbing et al. 2001); see also Padmanabhan's 2007 discussion, which highlights ethnic and subsistence-based differences in knowledge and responses among Ghana's Dagomba and Kusasi to the introduction of new crops and agricultural technologies, with both gendered and age-related negative implications. Such adverse effects are also exemplified by the ongoing erosion of Arawakan women's agrobiological knowledge,

36 Interestingly, Nakro (2006), who describes a project to strengthen Naga women's vegetable marketing, found an older and supportive Naga man valuing men's strength in harvesting and bringing home vegetable produce (tasks once the exclusive domain of women). Attitudes change. 
with young women failing to learn what is needed for food production in the Venezuelan Amazon (Hoffman 2003). ${ }^{37}$

Much of the literature on Southeast Asia describes a somewhat more equitable situation: although upland Vietnamese women are reported in Sen and An (2006) to suffer some disadvantages relative to men, both are actively involved in food production (men less than women). A similar situation exists among the Brou, Kri, Malang, Maleng, Atel and Témarou (hunter gatherers and shifting cultivators) in the forested Theun watershed of Laos (Chazée in press). See also Roberts (in press), on the Khmu, also of northeast Laos. The gendered division of agricultural labour on Semau (an island in West Timor, Indonesia) is described as shared and flexible (Gondowarsito 2002); something also found among many Bornean groups (cf. Colfer 2009, on the Kenyah; Colfer et al. 1999, Colfer et al. 2000, on the Iban; or Sutlive 1993, more broadly).

The literature from South Asia more closely parallels the inequities reported from Africa. Naga women play active roles, but also what Cairns (2007) considers an unfair share of the agricultural work load, combined with demanding domestic duties. Shan women (of southwest China) struggle with internal conflicts as they juggle childbearing and active agricultural roles (Yen 2009). Yen's findings contrast with those of $\mathrm{Du}$ (2000) who found an equitable division of agricultural and domestic duties among the Lahu (also in southern China).

Ritual responsibilities of men vis-à-vis women, related to agricultural production, have been highlighted among the Iban (Mashman 1993), and among the Bidayuh (Mashman and Nayoi in press), both of Borneo (see also Hoskins 1990 and Fowler in press on the Kodi of West Sumba). Alcorn et al. (2006), writing about rituals relating to maize in San Luis Potosí and Veracruz, Mexico, stress the important ritual roles of men in maize cultivation. Rituals often carry strong emotional meaning for both men and women, and can support or interfere with forest

37 Nascimento et al. (2012), unusually, found no significant difference between men's and women's knowledge of famine foods in Carão and Cachoeira, two villages in eastern Brazil. management, depending on how they are handled (and respected).

Types of fields-Farming systems often have multiple kinds of fields, with varying gender divisions of labour, decision making and benefit access. Whereas much agronomic and biodiversity research has focused on field crops, women are likely also to be active in other agroforestry habitats.

Floating gardens that women care for in the flooded forests of Mamirauá Reserve on the Amazon (also found in Danau Sentarum National Park in West Kalimantan, Colfer et al. 1993) have rarely been examined (Meola 2012). Only slightly more common is attention to landbased gardens (e.g. in Vietnam, Sen and An 2006; and in Nagaland, India, Nakro 2006, in their action research to empower women; see also Colfer 1991, on Javanese, Sundanese and Minangkabau home gardens in Sumatra). Many have noted both women's involvement and the important biodiversity functions of home gardens, swiddens and their fallows (e.g. Sajise in press on the Philippines; Chambers and Momsen 2007 in Bajío, Mexico). Home gardens (solar) can be differentiated as 'women's spaces' in contrast to the 'men's spaces', milpa, of more distant fields - where women rarely go and where their presence without their husbands is culturally disapproved-in Yaxcaba, a village in Yucatán, Mexico (Lopez-Alzina 2007). Food, medicine, fodder, fuel and ornamental plants are grown in the solares, which are recognised as sources of significant in situ agrobiodiversity, under women's control. In contrast to many gendered African crop preferences, in this site maize is seen as a predominantly male food crop, growing as it does in the milpa; squash is associated with both men and women. Torri (2012) also notes the 'feminised' nature of home gardens in her research among 'scheduled castes' in Tamil Nadu, India. She focused on describing and (positively) assessing a locally welcome programme to encourage medicinal herb cultivation in women's home gardens there-partially in response to the shortcomings of the formal medical system (linking with the meso level), partially because of people's inability to pay.

Migration-Migration's cultural significance (e.g. among the Rarámuri of northern Mexico, Miller 
2009; the Amazonian Mundurucú, Murphy and Murphy 2004), and its influence on men's and women's roles in food production surfaced again and again (e.g. in Uttar Pradesh and Bihar, India, Jassal 2012; or Bahío, Mexico, Chambers and Momsen 2007). In some places, old women and young girls are taking up the slack (Torri 2010, for Rajasthan, India) when other labour sources disappear. ${ }^{38}$ Kenyah women take pride in their ability to cope with hardship and to manage their fields on their own when husbands are away (Indonesian Borneo; Colfer 1985). Iban men's circular migration is central to their self-esteem, but Kedit (1993) also noted women's ambivalence about it and the centrality of rice production to women's own self-image and roles in Borneo.

Men's absence has clear impacts on women's traditional food production responsibilities in Kenya (Silberschmidt 2001, Shipton 2007). Shipton sees the preponderance of Kenya's outmigrating Luo, Luhya and Gusii men of working age as granting women increased decision making power. He describes what could be called 'sweat equity' among Luo women, even in situations where men have established rights to make decisions. Silberschmidt (2001) notes a similar pattern: the high degree of male out-migration has left many Gusii women (who head a third of households) 'for years on their own to manage the farm'.

Older women in some cases provide key safety net functions, remaining on the farm producing food. Elmhirst (2011), who examines migration patterns in southern Sumatra, notes:

'A common pattern of labour deployment ... was for older women to remain engaged in year-round food crop production, men and older sons to spend part of their time in coffee uplands working in plantations, whilst younger women took up 2-year contracts as overseas domestic workers'.

Female migration is important at the national level, particularly women migrants' remittances; they do, however, face dangers of abuse and exploitation,

38 See Federici (2004) for a controversial but fascinating Marxist interpretation of this implication (and others) of capitalism for women's lives. particularly those going to the Middle East and, to a lesser extent, Malaysia (Hugo 2002).

Climate change-A final broad topic has emerged recently: the links among gender, food production and climate change. Cameroonian women may become more vulnerable to climate change, given a) their lack of secure access to the land and forest resources on which they depend for food production and income, and b) their lack of voice in decision making related to climate change at all scales (Brown 2011). The UN-REDD Programme (2011) takes a pro-active stance, making a case for the value of women's food production knowledge and the need to understand fully both their activities and their constraints, for better REDD+ planning.

Boyd's (2009) critical assessment of Bolivia's Noel Kempff project acknowledges the recognition by climate change project personnel of women's active food production roles. But it found their attempts to organise communal vegetable plots initially flawed, with personnel unable or unwilling to change course based on women's explanations of their problems.

Some authors stress the differing perceptions and goals of men and women on this issue. (Anonymous 2012b) note women's dominance of food production in Mamberamo, in NE Papua (Indonesia). This author conducted systematic comparisons between local technical ecological knowledge and conventional climatological data, noting gender and community differences as well (including an informative table on gendered perceptions of seasonal events). S/he found, for instance, that 'men understand better how events influence the availability of the wildlife they hunt in the forest, and women how cultivated areas are affected'.

Djoudi and Brockhaus (2011) compared experiences and expectations of climate change in Mali, across gender, ethnic and livelihood dimensions; they found significant intracommunity differences in needs, experience and desired climate change adaptation paths for the future. Boyd, and Djoudi and Brockhaus all stressed the need to take women's views, constraints and wishes into account and to structure forest management efforts in ways that empower women as actors. 
Non timber forest products-Among many groups, the collection and/or management of non timber forest products falls to women (as noted earlier with regard to the shift from primarily subsistence-based to more commercial systems; see early but still relevant summary discussions in Sachs 1996).

Many emphasise the day to day use by women of food and firewood from nearby forests (cf. Gupte 2004 and Agarwal 2010, who stress the importance of the wild foods women collect in South Asia; in Nagaland, see the work of Cairns 2007, Nakro 2006). Young daughters-in-law and widows in Rajasthan may particularly experience discrimination as they collect necessary fuel wood, with such collection rendered illegal by the decisions of male- and elite-dominated community forest management groups (Torri 2010). Nepali women have significant experience-based knowledge of forest products-fuel wood, foods, fodder and medicines. WOCAN (2012) urges strengthening the links from their forest use and knowledge to efforts to address climate change (see also Anonymous 2012a, on Indian women's deep knowledge of foods and medicinal plants).

Women's interest in medicinal plants is worldwide (though not uniform) — as noted, for instance, by Boyd (2009) in Bolivia; Meola (2012) in Brazil; Leaman (1996) in Borneo; Roberts (in press) in Laos.

Women's and men's differences in interaction with NTFPs have been approached from a variety of perspectives. See, for instance:

- NTFP value chain analyses in Burkina Faso, Ethiopia and Zambia (Shackleton et al. 2011, see also shea production by women in Ghana (Chalfin 2004, Wardell in press).

- Cameroonian women's efforts to conserve the moabi tree for the many uses of its products, mentioned above (Veuthey and Gerber 2010).

- Female hunting among the Aka (pygmies) in the village of Mossapoula, within the DzangaSangha Special Reserve of southwestern Central African Republic (the Aka being among the most gender-equitable groups on earth). Women's hunting focuses on small animals and provides significant protein to families (Noss and Hewlett 2001).

- Differing gender patterns along the Amazon, from Porto Diaz in Acre where men are the prime actors in forests (timber, rubber, Brazil nuts), to Ludovico in Maranhão where women have had active roles as collectors, processors and sellers of the babaçu palm (Porro and Stone 2005).

- The more holistic view of Brazilian women vis$\grave{a}$-vis men about forest use-including concerns for food, medicines and culture-among people who comprise the National Council of Extractivist Populations (Shanley et al. 2011, a finding consistent with those of Bolaños and Schmink 2005, in Amazonian Bolivia; and forcefully and repeatedly argued by Shiva 1989 and others as universally applicable).

Livestock-The final recurring element related to economic roles is the tendency, remarked by World Bank (2009), for men to own larger animals (cattle, sheep, camels) and for women to own smaller ones (chickens). In some forested areas, such as the Amazon (or western regions of the US), cattle ranching represents a major problem for forests. In Nicaragua, in 2001, Deere et al. (2010) found a dramatic gender difference in animal ownership in the predicted direction: men owned cattle and work animals; women owned pigs and poultry. A study in Zambia linked women with chickens (Medvecky 2012); in Vietnam, women self-selected for a pigraising action/income-generation project (Sen and An 2006); Indonesia's West Timorese women preferred to raise goats (which can also be a problem for forest re-growth) and other small animals (Gondowarsito 2002). But contrary to expectation, in this latter group, men and women share cattle care (also found in a project in Satchari National Park, Bangladesh (Mukul et al. 2012). Shipton (2007) writes powerfully of the significance of cattle in Luo men's lives, particularly elderly men's, in his study of 'entrustment' in Kenya.

In concluding this sub-section, I am reminded of the study by Meinzen-Dick et al. (2012), who tried to map gendered farming systems in Africa (using Zambia and Ghana as test cases) — so many of which occur in or near forests. I concur with their general call for 'context-specific, genderdisaggregated data on agricultural (and forestry) production'; see also the High Level Panel of Experts 2011, which emphasises both women's active involvement in food production, but also the tendency to see 'men as the farmers'-an assumption even more common than gendered roles in forestry!). 


\subsubsection{Demography}

Although it has been unpopular to discuss population issues within the realm of natural resources for several decades, ${ }^{39}$ the topic has recently regained some 'social acceptability'; and I consider it an important one (of many), affecting both environmental and human conditions. I chose to emphasise the micro scale because of the powerful effects demographic factors have for women's involvement in forests. Population totals and density, family planning and migration all have been flagged as relevant for human involvement in forest management and other natural resource issues.

Human population totals and density-Much has been made of the links between increasing human population and forest loss; and there seems little doubt that population is one important factor in these trends. Yet the fallacy of assuming a straightline, global, causal link has also become clear. Flawed policy narratives about people's roles in habitat degradation have been rife (see convincing counter arguments by Fairhead and Leach 1996, Leach and Mearns 1996). The oft-cited Geist and Lambin (2002) concluded that the importance of population growth has been significantly overestimated. A global analysis of key drivers of deforestation in seven regions of the world found population increase to be central in only one of them (East Africa, Rudel 2005).

Other authors have identified links between population variables and women's status. In Southeast Asia, an historical congruence has been noted among low population density, femaledominated farming systems and high female status. ${ }^{40}$ This is particularly clear where matrilineal inheritance and matrilocal residence come into play (Andaya 2006). Such factors continue to play a role in women's access to and involvement in specific forests.
Considering demographic factors from the perspective of an individual woman can also be instructive. Using causal loop diagramming, Colfer et al. (2008) postulate likely causal links among such variables as 'desired number of children', 'access to family planning', 'involvement in subsistence labour', 'educational status' (and more). These authors see such factors as important (and variable) influences on women's lives and forest involvement at the micro level — with access to birth control being a particularly potent variable for opening up a whole range of forest-relevant possibilities for women.

Family planning - There is, of course, huge variation in the local acceptability of family planning. Child bearing is supremely important for the status of both Luo men and women, and children play crucial roles in economic security over the life cycle (in Kenya, Shipton 2007). In Zambia, Medvecky (2012) found significant masculine distaste for family planning. In some areas, men condemn it and women may desire it (parallel for instance to Jaquette's 2010 broader discussion of conflicts between indigenous rights and women's rights in Latin America). The women of Mamirauá (Amazonian Brazil) expressed dissatisfaction about their lack of access to birth control (Meola 2012)—something I have seen again and again in forested parts of the tropics. Hopefully unusually, elite men in a Shan Chinese village conspire in promulgating a myth that local women are able by traditional means to control their fertility and produce one male and one female child — a myth whose veracity is assured by means of selective infanticide; often against the mothers' wishes (Yen 2009).

On the other hand, in Southeast Asia, there is a long history of indigenous forms of birth control and abortion, despite disapproval from 'church and state' (Andaya 2006). More recently, Indonesia's family planning programme has been remarkably successful, overall (Hull and Adioetomo 2002)..$^{41}$ But Hull (1996) discusses the differential attitudes and practices between lower and middle class

41 My own experience in Long Segar, East Kalimantan included providing birth control in 1979 to local women, two of whom I trained to carry on, when I left in 1980. To my amazement, the community women managed to maintain access to birth control, without interruption, until my last visit (in 2004), and I suspect still have it.
39 Jiggins' early book (1994) represents a striking and useful exception. Although many details in the book are dated, important premises, observations and cautions apply today.

40 Colfer and Dudley (1993) provide detailed population information from several forested Bornean villages of Uma' Jalan Kenyah Dayaks, showing very slow growth rates (even prior to access to 'modern' family planning). 
women on Java, with increased fertility going hand in hand with improvements in socioeconomic status (a globally atypical finding, most frequently encountered in the Middle East).

The take-home messages here include the vast differences in attitudes among communities; often differential (including gendered) attitudes within communities must be noted and dealt with sensitively. The value of including women actively in any project or management planning becomes even more crucial with a sensitive topic like family planning.

Migration-Another demographic consideration with implications for women's involvement in forest management has to do with movement of people. The most dramatic range of material on this subject relates to men's out-migration, though women also migrate. ${ }^{42}$

Men's migration experiences affect both the men themselves and the women left behind. A number of authors have emphasised the adverse impacts of male migration on the men themselves. There are dramatic regional differences, which Jacobsen (2006) summarises, with women, for instance, dominating rural to urban migration in Latin America and men dominating such migration in Africa. Particularly dramatic difficulties are experienced by 'internally displaced' men in northern Uganda as they strive to gain the resources needed to start a family, and thus attain their ideal gender role (Barker and Ricardo 2006). These authors also note the frequency with which men throughout sub-Saharan Africa migrate in search of work..$^{43}$ Young men head off to war and to diamond pits in West Africa (from Senegal to Ghana) in yet another form of male migration (Richards 2006 discusses the factors involved in such decisions, emphasising people in forests; see also Richards 1996).

42 See Elmhirst's (2011) discussion of women's exclusion from local off-farm labour opportunities in Lampung (Sumatra), which resulted in a feminised 'reserve army of labour' (p. 181) for the network of brokers seeking women for domestic service in Malaysia, Hong Kong and Saudi Arabia.

43 In South Africa, for instance, in 2000, there were 350 000 black male workers in the mines- $95 \%$ from rural areas of South Africa, Botswana, Lesotho and Mozambique, most living far from home.
In some cases, disasters stimulate male migration. A terrible drought in Rajasthan led to major male out-migration in 1985-87 (Torri 2010; also highlighted as a factor by World Bank 2009). The 1983 El Niño drought in East Kalimantan resulted in high rates of out-migration from forests, some temporary, some permanent (Colfer and Dudley 1993). Taxation has, historically, been another important stimulus: Gusii men in Kenya, during the colonial period, migrated routinely to earn money to pay taxes (a pattern no longer found, Silberschmidt 2001); see also Wardell's (in press) historical account of this same colonial pattern in Ghana. Rwandan governmental policy requires rural youths to remain in rural areas, which become a kind of prison leading to youthful hopelessness (Sommers 2006); these youths have of course also lived through (some participating in) Rwanda's horrendous civil war. As climate change progresses, many expect tropical forests to be subjected to more intense disasters and unpredictability, further encouraging such migration.

In some cases, migrants send remittances home to forest areas. These can be a substantial, if uncertain, contribution to family finance (particularly key in Nepal, Leve 2007 and in El Salvador, Kelly 2009, where one-sixth of the population resides outside the country). For a discussion of the dependence combined with the unreliability of such remittances in Kenya, see Shipton (2007).

The most direct forest-related implication of male migration, though, is likely to be on women's workload (e.g. World Bank 2009 and Pruitt 2009, globally; Djoudi and Brockhaus 2011, in Mali; Wardell in press, in Ghana; Colfer 1985, in Borneo; Chambers and Momsen 2007, in Mexico). The short, work-related trips, required of community members who work with Mamirauá Reserve management (Brazil) create difficulties for both men and women who must cope with added work normally performed by the travelling spouse (Meola 2012).

There is also evidence that men's absence can result in advantages for women. Several authors have emphasised the potential for social change that broad patterns of migration can bring: Elmhirst (2008) discusses the 'instability' engendered by migration and mobility, as a potential source of positive change (see also Hugo 2002, on the sometimes-positive effects of women's international 
migration). Giri and Darnhofe (2010) did indeed find that Nepali women in Ramechhap district took on more public roles in community forest management in Nepal when their men had left (with variation in involvement dependent partially on the composition of the remaining family). Pruitt (2009) makes a similar point, seeing 'an opening for the renegotiation of gender roles'. The in-migration of individuals from different ethnic groups (non-Akan in Ghana; Javanese in Sumatra) can precipitate a mixing of divergent inheritance patterns (patrilineal and bilateral systems joining with existing matrilineal systems), likely to alter gender norms (Quisumbing et al. 2001). ${ }^{44}$

Shipton's (2007) observation of the stronger voices of Luo women who take on required additional labour in their husbands' absence in Kenya has already been mentioned, something noted also by Meinzen-Dick et al. (2012), in parts of Ghana. Seasonal factors can also be relevant: Bose (2011) describes the stronger role Bhil women had in forest management during the seasonal migration period when men were away, in Rajasthan.

\subsubsection{Women's valued domestic roles}

Although a central role of most women in all societies still involves care of families' domestic needs - child care and training, cooking, cleaning, care of the sick and elderly_-societies vary in both the specific allocation of tasks and the flexibility with which their accomplishment is viewed. Yet their accomplishment - in and of themselves-is vital in all societies. Such tasks also comprise a significant drain on the energies of whoever has responsibility for them, and can be serious constraints to forest involvement, particularly for women. Here I highlight cooking, childcare, women's forest-related knowledge and health care roles as central issues in women's involvement in forest management.

Cooking-Cooking can be centrally related to gender identity. In Indonesia's previous, formal governmental pronouncements about ideal women's roles, cooking featured centrally (Oey-

44 Colfer et al. (1989) found the local Minangkabau and the in-migrating Sundanese and Javanese transmigrants, each preferring different crops and agroforestry management strategies, with evolving implications for the division of labour, in central Sumatra.
Gardiner 2002). When members of a community in eastern Bolivia considered women's proposed involvement in a forest management project, they considered the most reasonable way to involve women was as cooks for field teams (Bolaños and Schmink 2005). Among the Malays of Trengganu, the masculinity of a man who cooked was called into question (Laderman 1996); yet not far from there, in Borneo among the Kenyah, men cook regularly without adverse social sanction. Similar flexible attitudes about cooking and gender roles were noted (throughout much of Southeast Asia, van Esterik 2008; among the Khmu of northeastern Laos, Roberts in press; and in eastern Indonesia, Gondowarsito 2002). Fowler (in press) notes related symbolic significance among the Kodi of Sumba (Indonesia): 'Trading fire is analogous to trading women. Fetching fire to revive a cold cooking hearth is metaphorical for enveloping good-looking, hard-working women into exogamous patrilines through marriage exchanges'.

In northern India, cooking involved an agerelated progression (Jassal 2012): young girls and women are relegated to the least skilled (and least enjoyable) cooking tasks, as helpers. In middle age, they take on the guiding, even commanding role, and in old age, they are relieved of cooking. Torri (2010) emphasises the pressure the young women of Rajasthan feel-responsible to provide the fuel wood needed to cook food, and unable to do so legally, as noted above. Incorporated with the ability to cook is typically a vast repertoire, among forest women, of knowledge about local plant and animal resources (see Anonymous 2012a), on the knowledge elderly Adi women (India) have about firewood, but also about wild edible plants and how to cook them; or see the collection by Howard 2003).

Women's cooking roles link them to forest management in many parts of the world by means of the need for cooking fuel and resulting involvement in collecting firewood (see, for instance, Sarin 2000, Agarwal 2001, Gupte 2004, for South Asia; Wan et al. 2011, or Mahat 2003, for global views) — though Jiggins (1994) reminds us that women's forest management involvement goes far beyond this issue. Recently, the potential relevance of women's fuel wood decisions for mitigating climate change has been highlighted (World Bank 2009), as women make decisions about cooking fuel efficiencies that could reduce carbon emissions. 
Women's knowledge and the enculturation of children-Such decisions, along with important links with children's enculturation, depend on the knowledge women possess. Many have noted the importance of women's knowledge in maintaining biodiversity (Mata and Sasvári 2009) —in agriculture, in preserving underused species, in medicinal plants (also noted by the World Bank 2009, globally; Anonymous 2012a, among elderly Adi women, India; Andaya 2006, historically for Southeast Asia; Howard's 2003 global collection). Older women's knowledge is particularly central in the saving of seed as well as the selection of planting materials in Andhra Pradesh, India, where women are seen as 'natural guardians' and 'keepers of agrobiodiversity' (Sajise in press). Yucatec Mayan immigrant women choose the species to bring with them to urban areas in Quintana Roo, according to Greenberg (2003). She finds a number of valued functions (ethnic continuity, maintenance of biodiversity, access to ingredients, shared consumption patterns, enculturation of the young and more) among this population. ${ }^{45}$

Women also have important roles in maintaining medicinal plants in Brazil (Sajise in press); or see Roberts (in press) on Khmu women's knowledge of medicinal plants, Laos. Uma' Tukung Kenyah women of the Apo Kayan (central Borneo) were somewhat more knowledgeable about plant remedies than men, and such knowledge was most common among older people (Leaman 1996). Mamirauá women played dominant roles in cultivation and processing of medicinal plants (Brazil; Meola 2012). In her study of local natural resource knowledge, she found that ' $(\mathrm{m})$ en named more species of fish, trees for various purposes, fish bait, fruit, eggs and vines while women named more species of seeds, medicinal plants and agricultural products'. Women, who accepted greater responsibility for family health, also expressed their overt efforts to teach local medical knowledge to the young. Such knowledge is closely related to women's frequent caretaking roles within families; and Meola (like Voeks 2007, in the eastern Amazon) fears its loss as local adults become more involved in wage labour.

45 She particularly notes the links between maintenance of cuisine and desired 'cultural control', the exercise of decision making about new cultural elements that people can reject, adopt or adapt (p. 63).
Torri (2012) expresses similar fears about medicinal plant knowledge in Tamil Nadu, India, where she worked with local women to reinforce such indigenous knowledge. Lyon and Hardesty (2012) describe how young Antanosy women (SE Madagascar) begin childbearing at around 14 years of age. They learn about forest products used for menstrual, reproductive and child care remedies early, from mothers, sisters and other female family and friends.

Health providers-Among many groups, women are the primary midwives (cf. Laderman 1987, or Jordan 1993) —often the only source of skilled medical assistance, in tropical forests (cf. global collection by Colfer 2008, or Kothari 2003, on women's health maintenance roles in an Ecuadorian village). Health also represents a more direct conduit to women since their roles in this sphere are more broadly acknowledged than in forestry. Ahmed and Fajber (2009) found, for instance, that women in Gujarat were included in a health committee in somewhat more equitable numbers than in the other village-level disaster committees developed to enhance local abilities to adapt to climate change. Both Meola (2012) in Brazil and Boyd (2009) in Bolivia found that their respective projects attended to women's health needs more readily than to women's needs in less gender-stereotyped realms.

These domestic tasks-cooking, enculturation of children and care of the sick-are clearly vital to human existence. They also routinely conflict with other human needs, such as food production/ gathering or income generation; they can also conflict with women's desires to better themselves, through education, volunteer work or collective action to improve local forest habitats.

There has, perhaps understandably, been a reluctance to attack this issue directly_partly because of predictable (sometimes inaccurately predicted) resistance from men. ${ }^{46}$ But genuine empowerment of women, and effective, benign use of women's significant energies, creativity and capabilities, will require more, and more flexible,

46 Cf. the comfort with and involvement in such tasks expressed among men in Aka, Kenyah and Lahu communities in Central African Republic, Borneo and southwestern China, respectively. 
involvement of men in the fulfilment of such domestic responsibilities. ${ }^{47}$

\subsubsection{Intra-household power dynamics}

Another rarely addressed topic within forestry, intra-household power dynamics, plays a crucial role in determining a) the degree to which women have options to become involved in forest management, $b$ ) the kinds of responsibilities they can (or must) take on and c) their involvement in decisions about the division of benefits from labour they may have provided. Here I focus on three issues: ${ }^{48}$ the different interests men and women may have, women's vulnerability to force and intra-household bargaining.

Product preference-A central and practical way in which women's interest can diverge from men's relates to product preference. The differing gendered attitudes toward Cameroon's moabi tree have already been mentioned (Veuthey and Gerber 2010). Pandolfelli et al. (2007), writing about factors related to collective action, note women's common concerns about taste and cooking features when evaluating crops, as compared to men's emphasis, which may be on marketability. Agarwal (2010) expands on another aspect of such a conflict in India: ' $[T]$ he everyday nature of women's subsistence need for firewood and fodder, which puts them under persistent pressure, and the occasional nature of men's subsistence need for timber, which allows them greater flexibility' (my italics) in India.

Such differences may be monetary: Meola (2012) found local stereotypes in Mamirauá (Brazil) suggesting that women were more likely to use household finances on family needs, while local people feared men would use them on alcohol (a concern also noted by Basu 2003, in India; by Amuyunzu-Nyamongo and Francis 2006, in Kenya). Luo men (western Kenya) preferred wealth

47 There is also evidence that such gender expectations can change: Nakro (2006) found the Naga men, for instance, willing to take on some traditionally female tasks in order to facilitate women's new opportunities to earn income (selling vegetables) that would benefit the entire family. Sen and An (2006) found men in Hue, Vietnam, increasingly taking their share in domestic responsibilities as women were involved in more training and as their women's incomes increased.

48 Gendered differences relating to access to land have already been discussed above. in livestock, whereas women preferred cash, a form more accessible for their use (Shipton 2007). Men and women in Bolivia had different expectations about the impacts of a forest management project in Bolivia (Bolaños and Schmink 2005). The men looked forward to the wage labour opportunities; the women were more fearful of the impacts on their own already overburdened work schedules. Accepting men's intra household decision making authority, they feared having to take on more of their husbands' usual agricultural tasks.

Vulnerability to force-Women's vulnerability to force renders such differences in gendered interests inequitable under many circumstances. Although Oey-Gardiner (2002) argues the women's movement in Indonesia has focused too much attention on domestic violence, other writers disagree (e.g. Baso and Idrus 2002, on South Sulawesi). In parts of India, such abuse can be at the hands of various family members, notably husbands or mothers-in-law (cf. Jassal 2012, who emphasises the dread tales sung about women who fail to follow cultural norms in north India). Women in a Maharashtra village in India were spurred to collective action against such violence (Gupte 2004); various strategies have been pursued by women (in Brazil, India, South Africa) to address this issue (Basu 2003). Alcohol consumption can be a precipitator of abuse, including molesting children in Mamirauá (Meola 2012). Parental abuse revolves around forced marriage (e.g. Leve 2007, on Nepal).

Several authors have linked increasing domestic violence with changing sex roles that are perceived to disadvantage men (e.g. Silberschmidt 2001, for East Africa, or Behrman et al. 2012b, who note a widespread perception that increasing women's access to resources can increase violence against them). Pandolfelli et al. (2007), on the other hand, found evidence that women's rights to land and other valued resources can serve to protect them from domestic violence.

Levels of such violence differ markedly from group to group. The Aka (Central African Republic), for instance, have minimal incidence of violence, particularly rare against women (Noss and Hewlett 2001). Both men and women can physically abuse their spouses in Madagascar (Gezon 2012); something I also noted, though rarely, among Kenyah Dayaks in East Kalimantan. The preponderance of use of 'husband-taming 
herbs', designed to 'control husband behaviour (especially infidelity), and promote love and harmony in marriage' is a striking $80 \%$ of women in a Zimbabwean resettlement community (Goebel 2003). She fully describes the links among women's access to herbs, gendered spaces and other social processes, including the frailty of women's access to land within a context of marital instability. In parts of Kenya and Tanzania, Silberschmidt (2001) found a predominance of men's fears about women poisoning them.

Women can be endangered at work-noted globally by the High Level Panel of Experts (2011). Lower-caste working women are subjected to routine violence and sexual abuse by the upper castes in India (Jayal 2003). And interaction with outsiders can also lead to violence against women: Aka women's vulnerability to rape by other ethnic groups who consider them sub-human was noted in the Central African Republic (Noss and Hewlett 2001); Meola (2012) notes fears of such violence as a barrier for women to travel to urban areas far from home (as Mamirauá conservation project duties can require); natural disasters represent situations of special danger for women (World Bank 2009).

Intra-household bargaining-This vulnerability to violence can serve as the basis for a seriously uneven playing field in what some label 'bargaining power'. There's little doubt that bargaining can play a significant role-moderated or exacerbated by cultural norms - in intra-household dynamics, with implications for forest management. Increased power for women has been found to occur:

- When external involvements result in enhanced self confidence: Amazonian women involved in a conservation project (Meola 2012); lowercaste women who received health-related training in Rajasthan, India (Torri 2012).

- When women gain increased incomes or wealth: globally (Pandolfelli et al. 2007); Nagaland, India, where men took on some gardening and other duties locally defined as domestic (Nakro 2006); Hue, Vietnam, where men began helping with household chores (Sen and An 2006); women's [temporarily] increased gardening incomes, in the Gambia (Schroeder 1999).

- When women's labour becomes more valuable for the household: Kenyan (Murang'a District) women's growing negotiating power as they became engaged in wage labour elsewhere, as a response to reduction in benefits from their production of coffee on lands owned by their men (Mackenzie 2005); Ghana, where women's labour in cocoa plantations became more vital (Quisumbing et al. 2004, Mackenzie 2005). ${ }^{49}$

In some contexts, women can be empowered by growing older: The women with the most likelihood to express their views publicly in Chivi, Zimbabwe were widows and elderly single women - with no husband to answer to (Nemarundwe 2005). Roberts (in press) notes the same tendency for older Khmu women in rural northeastern Laos. Women's strengthened decision making power when men are gone has already been discussed (male out-migration, above).

Sithole (2005) questions whether Zimbabwean women in Mafungautsi really want to have overt power locally. She found both men and women describing (and expressing a preference for) women's power to be 'subtle', 'hidden from view' 'bedroom tactics' and 'politics of the cooking pot'-an approach that allows women to influence events 'in ways that are not confrontational to established patriarchal systems and maintains the illusion of male-dominated spheres and women's subordination'. Sithole also notes the dangers locally of overt power for women, who can be labelled as witches or as sexually promiscuous (discussed more broadly for Africa by Federici 2008).

In a 'myth-busting' analysis, Mabsout and Van Staveren (2010) studied intra-household decision making in over 3000 households in Ethiopia. Counter intuitively, they found that increases in women's incomes did not necessarily result in increases in decision making power within their households. Instead, many women appeared to compensate for having taken on some of men's ideal responsibilities by more assiduously performing women's traditional responsibilities (including submission) as well.

Another factor among polygamous groups is the inclusion of a second wife. Both sexual jealousy and resentments about the need to divide material

49 Though see Dolan's (2001) analysis of men's usurpation of women's domain, and successful control of their labour for export-oriented horticultural production; and the strategies women used to counter such adverse impacts on their daily lives_-in Meru District, Kenya. 
benefits are key issues for polygamous households in a Malaysian fishing village (Laderman 1996). Interactions between co-wives and husbands in Sierra Leone vary from harmonious to conflicted, with wifely status ideally following the "order of arrival' of wives; this order is ideally reflected in the allocation of farming space as well (Leach 1992). This preferred hierarchy is sometimes disturbed by a 'favourite wife' who may be excused from farm work altogether (one life course-for particularly beautiful or charming young women only-that has long been one of few 'alternative livelihood paths' available to women).

\subsubsection{Alternative gendered livelihood paths}

Here I examine some of the more socially acceptable approaches that have been taken to empower women, some endogenous, some externally organised. A recurrent theme, with which this section begins, is the utility of collective action and networking for strengthening women's positions with special regard to natural resources. Another body of literature focuses on the potential conflicts between women's domestic responsibilities and income generation. The final subsection looks at issues pertaining to micro finance and the use and distribution of benefits within households.

Networking and collective action-Collective action is defined here as 'the process by which voluntary institutions are created and maintained and to the groups that decide to act together' (Pandolfelli et al. 2007). Many see collective action as a crucial key to women's empowerment and general food security (Tripathi et al. 2012). These authors also stress the enhancement of disaster preparedness and resilience (e.g. in Tajikistan), and climate change preparedness. Others consider that the resulting social capital can help to mitigate adverse shocks (Behrman et al. 2012b). Women's collective action is a possible route to increasing their access to resources (World Bank 2009). Ahmed and Fajber (2009) urge us to strengthen collective action among women based on their research in Gujarat, India. Such collective action can have national implications, such as the Green Belt, tree planting movement in Kenya spearheaded by Nobel Prize winner Wangari Maathai, or the Chipko movement, which protected forests in India.
Men's involvement in collective action has been rather widely assumed. Sadly, the gender literature has so far emphasised the adverse effects of collective action among men (despite the fact that men group for many positive purposes as well-political action, labour unions, community improvement, conservation or development efforts); see many examples in Colfer (2005) and other materials from the Center for International Forestry Research's Adaptive Collaborative Management (ACM) programme; http://www.cifor.org/acm/beyond/.

Links between collective action and violence have, however, been noted by many. Men's grouping behaviour has been supportive of extreme male violence in Colombia (Alcaraz and Suárez 2006). These authors suggest 'deactivat[ing] the logic of collective coercion that harms men as much as the rest of society..$^{50}$

Mitigating domestic violence was a 'popular' topic in India. The women in Maharashtra, mentioned above, who formed into groups, had come together a decade earlier to reduce men's alcohol consumption and the resulting domestic violence and loss of income in their communities (Gupte 2004). ${ }^{51}$ Women in the generally less 'progressive' Rajasthan also formed women-only assemblies to protest the dowry system and domestic violence (Torri 2010).

Women routinely come together for economic and conservation purposes. In eastern Cameroon, women formed CIGs (special interest groups encouraged by the government) to protect, develop and further commercialise moabi oil (Veuthey and Gerber 2010). In southern Cameroon, local women organised less formally to protest the activities of the government-supported Campo-Maan protected area (Tiani et al. 2005).

Protection, strength in numbers, is the rationale for Aka women (Central African Republic) hunting in groups (Noss and Hewlett 2001). Indian women

50 Doyle (2002) also links use of sex workers with men in groups drinking alcohol, in Vietnam.

51 'Women are active in women's groups (called Mahila Mandals), involved in activities like managing savings schemes and ensuring financial security; ensuring continued prohibition of alcohol; supporting victims of alcohol abuse; managing the stone quarry in the village, including taking care of labour payments, government royalties, and so forth.' (p. 374). 
involved themselves proactively, with NGO help, in developing water storage embankments and other conservation measures in a recently deforested area designed partly to improve year-round availability of water for their crops (Torri 2010). Agarwal (2010) outlines a whole range of reasons that Indian women act collectively and in informal groups; Arora-Jonsson (2005) emphasises the different institutional and interactional preferences she found among Swedish and Indian women vis-à-vis those of their male compatriots. Both Arora-Jonsson and Giri and Darnhofer (2010), who examine community forest user groups in Nepal, emphasise the importance of observing and building on local processes, rather than focusing only on institutional structures. Arora-Jonsson's (2013) most recent work concludes that our emphasis on public and visible group action represents a general, gendered (male) bias. She elaborates on the informal and often publicly invisible actions she found among Indian and Swedish women's approaches to forest management, and she stresses the importance of separate spaces for women to gather. Jeannette Gurung, on the other hand, sees the formal institutional barriers, reinforced by forestry departments and training institutions, as key factors in women's exclusion from effective participation in forest management (e.g. WOCAN 2012).

Women's health care responsibilities are another frequent 'excuse' for grouping; lower-caste women in India come together to better manage herbal gardens (Torri 2012):

'Over the last 15 years, more than 190000 home herbal gardens have been established by the community-based organisations, which are mainly women's self-help groups in more than 6000 villages and hamlets across the states of Kerala, Karnataka and Tamil Nadu'.

Two related strategic approaches are emphasised in the literature: political strategising and the utility of multi-scale action. With regard to the former, in Sierra Leone, a woman leader brought men into her group to help the men understand women's perspectives, with good results (Tripathi et al. 2012). Agarwal (2010) discusses the dominance of Indian women in agitational movements like chipko $^{52}$ (see also Moore 1993, in a Zimbabwean

52 Though Arora-Jonsson (2013) questions this interpretation; and several authors have stressed Chipko's relevance as a peasant movement rather than a women's movement. resettlement area, where women protested their eviction from a park; Schroeder 1999, on Gambian women gardeners' protest about a land dispute; or Federici 2011, with various African examples-all also important cross-scale actions). In Gujarat, women's extant collective mobilisation helped them negotiate more effectively with government for services (Ahmed and Fajber 2009). Mabsout and Van Staveren (2010) recommended that those seeking to empower Ethiopian women work through groups, especially in the most gender-inequitable ethnic contexts. Occasionally women become village heads (e.g. Roberts in press, on a woman village head among the Khmu of Laos). Nussbaum et al.'s (2003) collection identifies constraints to female involvement in formal political systems, mainly in India.

Networking can also be of strategic value: Kodi matriclans in Sumba (Indonesia) maintain and strengthen ties among women (Hoskins 1990). Anonymous (2012a) notes both the efforts of NGOs to strengthen collective action and networking among elderly Adi women in India, but also notes significant existing networking underway. Gupte (2004) predicted that more networking among the women of conservative Rajasthan would be to their advantage. The need for information (in a Zimbabwean case, on 'husband-taming herbs', Goebel 2003) can also encourage the expansion of female friendship networks.

Men tend to have bridging social capital (linking across social boundaries), whereas women tend to have bonding social capital (linking within social boundaries) — with different implications for access to external resources (Pandolfelli et al. 2007). Women gardeners in Chivi, Zimbabwe, gained significant advantage by seeking external help and by acting at multiple scales. In this setting, Nemarundwe (2005) found that 'where women cannot employ internal strategies, they now rely on external development facilitators for support to ensure that their views are considered'. Shanley et al. (2011) examine the National Council of Rubber Tappers in Brazil, clearly tracing women's involvement and their efforts and successes at multiple levels.

As noted in the case of men and collective action, not all collective action has positive results. A thorough gendered analysis of the implementation of India's Forest Rights Act in the Banswara District of Rajasthan reveals the legislation failed to strengthen tribal rights to forests, partially through 
group management, as intended. Bose (2011) found that many experienced, Bhil tribal women, whose traditional status and influence had been high, and who shared work in functioning traditional groups, were excluded from the new, Forest Rights Act management groups. The Bhil women were replaced by more acculturated and literate women who were less dependent on, and less knowledgeable about, forest resources. It is not uncommon for elites to coopt collective action groups.

In Mamirauá (Brazilian Amazon), the conservation project encouraged formal collective action among women; in fact, the women were reducing their traditional community work days because many no longer had agricultural fields (Meola 2012). Another study found women reluctant to sanction their group members, fearing to damage their own social capital (in Kenya, Uganda, Bolivia and Mexico; Mwangi et al. 2011).

On the plus side, in Bangladesh, women's involvement in water management groups reduced conflicts, quickened startup activities and enhanced respect for the rules (Pandolfelli et al. 2007); see also Colfer 2005, for an analysis of 30 adaptive collaborative management sites across the tropics, most of which strengthened collective action in useful ways, and in a number of cases, among women; or Agarwal's 2001, thorough analysis for South Asia.

Income generation-The second topic, in this subsection, focuses on income generation and the constraints to women's moving forward in the economic realm. Many authors note the importance of compatibility of new economic alternatives with existing domestic roles. In three cases of NTFP collection, processing and sale examined in Burkina Faso, Ethiopia and Zambia, women's traditional domestic responsibilities formed constraints to their wider involvement in related value chainsconstraints reinforced by normative gender roles (Shackleton et al. 2011). Amazonian women were drawn to artistic handicraft production for tourists as an economic endeavour more flexible and compatible with their domestic duties than most such options (Meola 2012). Some have seen a compatibility between processing crops and traditional 'feminine' household tasks (MeinzenDick et al. 2012).

Hunting is the NTFP context from which women are most frequently absent (though see Du 2000, who writes of myths among the comparatively gender-equitable Lahu [China] about men and women hunting big game together). Besides showing the frequency with which Aka women hunt in the Central African Republic, Noss and Hewlett (2001) provide a thorough review of the literature on this subject. They note also that Aka women's net hunting may be more compatible with childcare than other hunting technologies (to which local women also have free access). ${ }^{53}$

A related incompatibility, that of women's domestic duties and their access to politics, was noted by many as well: see the global review by Colfer (2011); a thorough account of women's political challenges in Brazil, many stemming from conflicts between private and public responsibilities (Shanley et al. 2011); or the collection by Nussbaum et al. (2003), primarily focused on India. According to Basu (2003), Indian women prefer informal, democratic and geographically close involvement in politics. She argues for the fuller integration of the public and private spheres into local policy making, which renders women's concerns clearer at that level than at broader scales/ higher policy levels. Whereas Basu considered issues at higher levels to be more differentiated, with women's concerns tending to disappear from view, Arora-Jonsson (2013) found the same thing happening at the local level (in both Sweden and India). Women's comparative lack of time to attend meetings and consultations, which resulted in less knowledge of REDD+ activities than men, also formed a serious constraint to women's meaningful involvement (UN-REDD Programme 2011; see also WOCAN 2012, Nepal).

Women's time constraints have been frequently noted: women sometimes serve as 'shock absorbers', increasing their labour to cope with the impacts of structural adjustment programmes in developing countries (Pandolfelli et al. 2007). Climate change is anticipated to bring even greater hardships for women, as they will have to walk farther for fuel wood and water in a hotter world (World Bank 2009). Lack of time was a

53 Veuthey and Gerber (2010) argue that Bantu women of eastern Cameroon are prevented from hunting by a taboo on their using iron tools; however, I did not find their argument convincing, in light of both my own observations and the evidence they provide. Meinzen-Dick et al. (2012) make a better case for the general ways in which women are disadvantaged in gaining access to tools and other inputs. 
significant constraint to women's investment in forest management activities like tree planting and clearing undergrowth in Kenya, Uganda, Bolivia and Mexico (Mwangi et al. 2011).

Gendered time issues involve more than the simple quantity of tasks, as highlighted by Agarwal (2010): women's traditional domestic tasks tend to be unpredictable and ongoing throughout the day (and night, in the case of child- and eldercare), whereas men's tasks may well involve short bursts of intense energy and/or strength. There may be seasonality to time demands that differ by gender (cf. Dolan's 2001, discussion of such conflict in Kenya). There may be differences in the gestation of crops (women may grow, use and sell quick annuals; men, long-lived timber species) -all of which have implications for conflict. A final and pervasive issue remains the differences among women in any given community (ethnic, age, marital status, caste, class, religion, etc.). These cross-cutting characteristics can be as significant for both time constraints and for forest management as the differences between men and women.

Use and distribution of benefits-So, what are the impacts of these constraints in terms of benefit distribution and women's access to resources? Many donors, project managers and economists assume a unitary household purse controlled by men. Yet in many parts of the world, husbands and wives maintain separate control of their income flows (cf. Quisumbing et al. 2004, on Ghana). In other parts of the world (e.g. much of Southeast Asia), women may traditionally control household purse strings.

A second key issue has been the actual use of funds that accrue to a household. Many have emphasised the greater likelihood that women will use income for the benefit of the family, whereas men may be found to fritter it away on drink (e.g. Nightingale 2011, on Nepal; Amuyunzu-Nyamongo and Francis 2006, on Kenya). Meinzen-Dick et al. (2012) summarise other literature, concluding that 'increasing women's control over resources has positive effects on a number of important development outcomes, including food security, child nutrition and education' (World Bank 2009 provides additional specifics).

There are disadvantages to attending only to women as we consider gender and the distribution of benefits; one of these disadvantages involves adverse responses from men to women's economic successes (Correia and Bannon 2006). These authors highlight the evidence that, in some areas, men's responses have been

'...to seek other ways of asserting their
masculinity, including resorting to illicit
and criminal behaviour to earn income and
status or taking out their frustration and
anger through the use of violence, alcohol
and substance abuse, and suicide. Taking out
their frustrations through the oppression of
less powerful individuals, such as women and
youth, is also a common reaction'.

A quantitative study of intra-household decision making in Ethiopia came to a similar conclusion about women's financial successes: that such success exposed women to additional abuse and reduced bargaining power within their households (Mabsout and Van Staveren 2010). The tendency for men to 'take over' when a crop becomes more profitable has also been noted above and by many (e.g. Veuthey and Gerber 2010, in Cameroon; Dolan 2001, in Kenya; Andaya 2006, on Southeast Asian history).

Some authors have found women to be particularly creative in finding niches from which to wrench economic advantage. Such creativity, along with the links between the emotional ${ }^{54}$ and the economic, were evident among the women of Madagascar. Gezon (2012) concludes that '(w)omen's autonomy and entrepreneurial spirit have facilitated the establishment of the khat economy'.

Gezon's interpretations are a fitting conclusion to this micro-scale discussion, emphasising as she does the significance of emotion in women's interactions with natural resources and with the economy. Many authors have urged us to open up forestry to a broader conceptualisation, one that genuinely takes into account the views, knowledge, goals of women as well as men. Such an opening up will be necessary if we truly want to incorporate both men and women into more equitable (and hopefully more effective) forest management.

54 See Gandhi and Shah (1992) who also recognise and value emotive elements in women's lives. They speak of the women's movement: 'It has always existed as an emotion, an anger deep within us, and has flowed like music in and out of our lives, our consciousness and actions' (p. 15). 


\section{Conclusions and ways forward}

A s Lidestav and Reed (2010) point out, the issues discussed here '.... will not be resolved merely by adding women to the mix of decision makers. Rather, [they] will require serious examination and reflection on longstanding cultural assumptions and practices'.

If we take seriously the conclusion that gender involvement in forest management requires a holistic, systemic perspective, the research gaps are indeed gaping. Initial assessment in each forest and community would need to be conducted-an improbable outcome. But the simple identification of issues to keep in mind can move us forward toward more aware and conscious forest-related decision making.

Conclusions about what needs to be done- there is so much!- -are seriously influenced by the values of the person making the recommendations. Bearing that in mind, I see the following as particularly useful directions:

The easy ones:

- Be more equitable in research and development efforts-examining and incorporating both men's and women's needs, interests, behaviours, values, expectations/hopes for the future, into the planning, implementation, assessment and recurrent revisions of natural resource management, development and conservation plans.

- Pay less attention to cash, more to nonmonetary values that men and women assign to forests in the different locales where we work. ${ }^{55}$

55 Reed and Christie (2008) follow Davidson and Stratford (2007), in explicitly linking the 'economistic' with masculine values and 'care' values with women: '...that resource management continues to focus on more economistic and use values rather than "care" values may help explain why some voices [women's and other marginalised groups] in these debates remain silenced while others dominate' (p. 252).
Such values represent potent opportunities for effective collaboration with local men and women — something ultimately needed if forests are to continue to cover significant parts of the Earth.

- Situate our efforts time-wise, by examining local historical contexts/trends and identifying the often-differing preferences of men and women about future expectations and desires.

The harder ones:

- Attend more seriously to the recurring dilemma of how much effort to expend within existing gendered patterns of behaviour (helping women with fuel wood collection, for instance); and how much on riskier, but potentially more powerful approaches, ones that can more effectively begin to level the playing field (collaborative gender assessment of winners and losers in a local forest, for instance).

- Work more on strategies that can enlist the help of both men and women in equity enhancement in forests, publicly and privately. Identifying good strategies is a legitimate research topic; and working on equity explicitly with communities has shown good results.

- Strengthen our abilities as professionals to work together in genuinely interdisciplinary fashion and across-scale. The interactions among features at different scales have been widely ignored, despite increasingly obvious impacts. Similarly, looking backwards and forward in time has not been adequately valued-as we try to fit management plans to local contexts. Both scale and time issues require input from multiple disciplines.

There is no end, I imagine, to the human effort to improve our lives; but with regard to gender, we have much to accomplish. May this framework, summarised in the gender box, contribute to our ability to address the needs of both women and men more broadly and effectively! 


\section{References}

Agarwal, B. 2001 Participatory exclusions, community forestry and gender: an analysis for South Asia and a conceptual framework. World Development 29 (10): 1623-1648.

Agarwal, B. 2010 Gender and green governance: the political economy of women's presence within and beyond community forestry. Oxford University Press, Oxford, UK.

Ahmed, S. and Fajber, E. 2009 Engendering adaptation to climate variability in Gujarat, India. In: Terry, G. (ed.) Climate change and gender justice. Practical Action Publishing, Oxford, UK.

Alcaraz, F.H.G. and Suárez, C.I.G. 2006 Masculinity and violence in Colombia: deconstructing the conventional way of becoming a man. In: Bannon, I. and Correia, M.C. (eds.) The other half of gender: men's issues in development. World Bank, Washington, DC.

Alcorn, J.B., Edmonson, B. with Vidales, C.H. 2006 Thipaak and the origins of maize in northern Mesoamerica. In: Staller, J.E., Tykot, R.H. and Benz, B.F. Histories of maize in Mesoamerica: multidisciplinary approaches. Elsevier Press, New York.

Allotey, P., Gyapong, M. and Colfer, C.J.P. 2008 The gender agenda and tropical forest diseases. In: Colfer, C.J.P. (ed.) Human health and forests: a global overview of issues, practice and policy. Earthscan, London.

Amuyunzu-Nyamongo, M. and Francis, P. 2006

Collapsing livelihoods and the crisis of masculinity in rural Kenya.. In: Bannon, I. and Correia, M.C. (eds.) The other half of gender: men's issues in development. World Bank, Washington, DC.

Andaya, B.W. 2006 The flaming womb: repositioning women in early modern Southeast Asia. University of Hawai'i Press, Honolulu, Hawaii, US.

Anonymous 2012a [under review] Elderly Adi women of Arunachal Pradesh: 'living encyclopedias' and cultural refugia in biodiversity conservation of the eastern Himalayas, India. Submitted to Environmental Management.
Anonymous 2012b [under review] Local perceptions of climate variability and change in tropical forests of Papua (Indonesia). Submitted to Ecology and Society.

Arora-Jonsson, S. 2005 Unsettling the order: gendered subjects and grassroots activism in two forest communities. Natural Resources and Agricultural Sciences, Swedish University of Agricultural Sciences, Uppsala, Sweden.

Arora-Jonsson, S. 2009 Discordant connections: discourses on gender and grassroots activism in two forest communities in India and Sweden: winner of the 2009 Catharine Stimpson Prize. Signs 35 (1): 213-240.

Arora-Jonsson, S. 2013 Gender, development and environmental governance: theorizing connections. Routledge, New York.

Bandiaky-Badji, S. 2011 Gender equity in Senegal's forest governance history: why policy and representation matter. International Forestry Review 13 (2): 177-194.

Barker, G. and Ricardo, C. 2006 Young men and the construction of masculinity in subSaharan Africa: implications for HIV/AIDS, conflict and violence. In: Bannon, I. and Correia, M.C. (eds.) The other half of gender: men's issues in development. World Bank, Washington, DC.

Baso, Z.A., and Idrus, N.I. 2002 Women's activism against violence in South Sulawesi. In:

Robinson, K. and Bessell, S. (eds.) Women in Indonesia: gender, equity and development. Institute of Southeast Asian Studies, Singapore.

Basu, A. 2003 Gender and governance: concepts and contexts. In: Nussbaum, M., Basu, A., Tambiah, Y. and Jayal, N.G. (eds.) Essays on gender and governance. Human Development Resource Centre, United Nations Development Programme, New Delhi, India.

Behrman, J., Meinzen-Dick, R. and Quisumbing, A. 2012a Understanding gender and culture in agriculture: the role of qualitative and quantitative approaches. In: Quisumbing, A., Meinzen-Dick, R., Raney, T., Croppenstedt, A., Behrman, J.A. and Peterman, A. (eds.) Gender in agriculture 
and food security: closing the knowledge gap. Springer, New York.

Behrman, J., Karelina, Z., Peterman, A., Roy, S. and Goh Goh, A. 2012b A toolkit on collecting gender $\&$ assets data in qualitative $\&$ quantitative program evaluations. Gender, agriculture and assets project. International Food Policy Research Institute and International Livestock Research Institute, Washington, DC.

Bellassena, V. and Gitz, V. 2008 Reducing emissions from deforestation and degradation in Cameroon-assessing costs and benefits. Ecological Economics 6 (1\&2): 336-344.

Benjamin, A.E. 2010 Women in community forestry organizations: an empirical study in Thailand. Scandinavian Journal of Forest Research 25: 62-68.

Bergink, D. 1987 The Tolaki female gender in procreation and production. In: LocherScholten, E. and Niehof, A. (eds.) Indonesian women in focus: past and present notions. Foris Publications Holland, Dordrecht, The Netherlands.

Bolaños, O. and Schmink, M. 2005 Women's place is not in the forest: gender issues in a timber management project in Bolivia. In: Colfer, C.J.P. (ed.) The equitable forest: diversity, community and resource management. Resources for the Future/CIFOR, Washington, DC.

Bose, P. 2011 Forest tenure reform: exclusion of tribal women's rights in semi-arid Rajasthan, India. International Forestry Review 13 (2):220-232.

Bourdier, F. 2013 Change and permanence in swidden agriculture: among the Tampuan in Ratanakiri province, Cambodia. In: Cairns, M. (ed.) A growing forest of voices. Earthscan, London.

Boyd, E. 2009 The Noel Kempff project in Bolivia: gender, power and decision making in climate mitigation. In: Terry. G. (ed.) Climate change and gender justice. Practical Action Publishing, Oxford, UK.

Brown, H. C. P. 2011 Gender, climate change and REDD+ in the Congo Basin forests of Central Africa. International Forestry Review 13 (2):163-176.

Brown, K. and Lapuyade, S. 2001 Changing gender relationships and forest use: a case study from Komassi, Cameroon. In: Colfer, C.J.P. and Byron, Y. (eds.) People managing forests: the links between human well being and sustainability. Resources for the Future/ CIFOR, Washington, DC.

Cairns, M. 2007 The alder managers: the cultural ecology of a village in Nagaland, NE India. Ph.D. Thesis, Research School of Pacific and Asian Studies, Australian National University, Canberra, Australia.

Cairns, M. 2013 (ed.) A growing forest of voices. Earthscan, London.

Campbell, C., Chicchón, A., Schmink, M. and Piland, R. 2005 Intrahousehold differences in natural resource management in Peru and Brazil. In: Colfer, C.J.P. The equitable forest: diversity, community and resource management. Resources for the Future/ CIFOR, Washington, DC.

Chalfin, B. 2004 Shea butter republic: state power, global markets and the making of an indigenous commodity. Routledge, New York.

Chambers, K.J. and Momsen, J.H. 2007 From the kitchen and the field: gender and maize diversity in the Bajío region of Mexico. Singapore Journal of Tropical Geography 28:39-56.

Chazée, L. 2013 Valuation and management of forest ecosystem services: a skill well exercised by the forest people of Upper Nam Theun, Lao PDR. In: Cairns, M. A Growing Forest of Voices. Earthscan, London.

Chevannes, Barry 2006 The role of men in families in the Caribbean: a historical perspective. In: Bannon, I. and Correia, M.C. (eds.) The other half of gender: men's issues in development. World Bank, Washington, DC.

Colfer, C.J.P. 1983 Change and indigenous agroforestry in the forests of East Kalimantan. Borneo Research Bulletin $15(1,2): 3-20 ; 70-86$.

Colfer. C.J.P. 1985 On circular migration: from the distaff side. In: Standing, G. Labour circulation and the labour process. Croom Helm, London.

Colfer, C.J.P. 1991 Toward sustainable agriculture in the humid tropics: building on the TropSoils experience in Indonesia. TropSoils Technical Bulletin 91/02. North Carolina State University, Raleigh, North Carolina.

Colfer, C.J.P. 2005 The complex forest: communities, uncertainty, and adaptive collaborative management. Resources for the Future/CIFOR, Washington, DC.

Colfer, C.J.P. (ed.) 2008 Human health and forests: a global, interdisciplinary overview of issues, practice and policy. Earthscan/ CIFOR, London. 
Colfer, C.J.P. 2009 The longhouse of the Tarsier: changing landscapes, gender and well being in Borneo. In: Appell, G.N. and Sutlive, V.H. Borneo Research Council Monograph Series 10. Borneo Research Council, in cooperation with CIFOR and UNESCO, Phillips, Maine, US.

Colfer, C.J.P. 2011 Marginalized forest peoples' perceptions of the legitimacy of governance: an exploration. World Development 39 (12): 2147-2164.

Colfer, C.J.P. and Dudley, R.G. 1993 Shifting cultivators of Indonesia: managers or marauders of the forest? Rice production and forest use among the Uma' Jalan of East Kalimantan, Community Forestry Case Study Series 6. Food and Agriculture Organization of the United Nations, Rome.

Colfer, C.J.P. and Minarchek, R.D. 2012 Women, men and forest research: a review of approaches, resources and methods for addressing gender. CIFOR Occasional Paper 80. CIFOR, Bogor, Indonesia.

Colfer, C.J.P., Amoi and Suriansyah, B. 1993 Floating gardens. In: Dudley, R.G. and Colfer, C.J.P. (eds.) Conservation sub-project quarterly report and attachments. Asian Wetlands Bureau, Bogor, Indonesia.

Colfer, C.J.P., Dudley, R.G. and Gardner, R. 2008 Forest women, health and childbearing. In: Colfer, C.J.P. Human health and forests: a global overview of issues, practice and policy. Earthscan, London.

Colfer, C.J.P., Gill, D. and Agus, F. 1988 An indigenous agroforestry model from West Sumatra: a source of insight for scientists. Agricultural Systems 26: 191-209.

Colfer, C.J.P., Newton, B. and Herman 1989 Ethnicity: an important consideration in Indonesian agriculture. Agriculture and Human Values VI (3): 52-67.

Colfer, C.J.P., Wadley, R.L. and Venkateswarlu, P. 1999 Understanding local people's use of time: a precondition for good co-management. Environmental Conservation 26: 41-52.

Colfer, C.J.P., Wadley, R.L., Salim, A. and Dudley, R.G. 2000 Understanding patterns of resource use and consumption: a prelude to co-management. Borneo Research Bulletin 31: 29-88.

Colfer, C.J.P. with Andriamampandry, E., Asaha, S., Basuki, I., Boucard, A., Feintrenie, L., Ingram, V., Roberts, M., Sunderland, T. and Urech, Z.L. 2011 Minefields in collaborative governance. In: Colfer, C.J.P. (ed.) Collaborative governance of tropical landscapes. Earthscan, London.

Colfer, C.J.P., Minarchek, R.D., Aier, A., Cairns, M., Doolittle, A., Mashman, V., Odame, H.H., Roberts, M., Robinson, K. and van Estrik, P. 2013 Gender analysis and indigenous fallow management $I n$ : Cairns, M. A growing forest of voices. Earthscan, London.

Correia, M.C. and Bannon, I. 2006 Gender and its discontents: moving to men-streaming in development. In: Bannon, I. and Correia, M.C. (eds.) The other half of gender: men's issues in development. World Bank, Washington, DC.

Cronkleton, P. 2005 Gender, participation and the strengthening of indigenous forest management in Bolivia. In: Colfer, C.J.P. The equitable forest: diversity, community and resource management. Resources for the Future/CIFOR, Washington, DC.

D'Agnes, L. and Margoluis, C. 2007 Integrating population, health and environment (PHE) projects: A programming manual. USAID Office of Population, Health and Environment, Washington, DC.

Dangol, S. 2005 Participation and decision making in Nepal. In: Colfer, C.J.P. The equitable forest: diversity, community and resource management. Resources for the Future/ CIFOR, Washington, DC.

Deere, C.D., Alvarado, G.E. and Twyman, J. 2010 Gender inequality in asset ownership in Latin America: Female owners vs. household heads. Development and Change 43 (2): 505-530.

Diabate, N. 2011 Genital power: female sexuality in West African literature and film. Ph.D Thesis, University of Texas, Austin, US.

Diaw, M.C. 2005 Modern economic theory and the challenge of embedded tenure institutions: African attempts to reform local forest policies. In: Kant, S. and Berry, R.A. Sustainability, institutions and natural resources: institutions for sustainable forest management. Springer, Netherlands.

Djoudi, H. and Brockhaus, M. 2011 Is adaptation to climate change gender neutral? Lessons from communities dependent on livestock and forests in northern Mali. International Forestry Review 13 (2): 123-135.

Dolan, C. 2002 Collapsing masculinities and weak states - a case study of northern Uganda. In: Cleaver, F. Masculinities matter! Men, gender and development. Zed Books, New York. 
Dolan, C.S. 2001 The 'good wife': struggles over resources in the Kenyan horticultural sector. Journal of Development Studies 37 (3): 39-70.

Dove, M. 2011 The banana tree at the gate: a history of marginal peoples and global markets in Borneo. Yale University Press, New Haven, Connecticut, US.

Doyle, N. 2002 Why do dogs lick their balls? Gender, desire and change-A case study from Vietnam. In: Cleaver, F. Masculinities matter! Men, gender and development. Zed Books, New York.

Du, S. 2000 'Husband and Wife Do It Together': Sex/gender allocation of labor among the Qhawqhat Lahu of Lancang, Southwest China. American Anthropologist 102 (3): 520-537.

Elmhirst, R. 2008 Multi-local livelihoods, natural resource management and gender in Upland Indonesia. In: Resurreccion, B.P. and Elmhirst, R. (eds.) Gender and natural resource management: Livelihoods, mobility and interventions. Earthscan, London.

Elmhirst, R. 2011 Migrant pathways to resource access in Lampung's political forest: gender, citizenship and creative conjugality. Geoforum 42: 173-183.

Fairhead, J. and Leach, M. 1996 Misreading the African landscape: society and ecology in a forest-savanna mosaic, African Studies Series 90. Cambridge University Press, Cambridge, New York.

Federici, S. 2008 Witch-hunting, globalization and feminist solidarity in Africa today. Journal of International Women's Studies 10 (1): 21-35.

Federici, S. 2011 Women, land struggles and the reconstruction of the commons. Working USA: The Journal of Labor and Society 14: 41-56.

Fortmann, L. and Bruce, J. (eds.) 1988 Whose trees: proprietary dimensions of forestry. Westview Press, Boulder, Colorado, US.

Fowler, C. 2012 Ignition stories: indigenous fire ecology in the Indo-Australian monsoon zone. Carolina Academic Press, Durham, North Carolina, US.

Fresco, L.O. 1986 Cassava in shifting cultivation: a systems approach to agricultural technology development in Africa. Royal Tropical Institute, Amsterdam, The Netherlands.

Geist, H.J. and Lambin, E.F. 2002 Proximate causes and underlying driving forces of tropical deforestation. BioScience 52 (2): 143.
Gezon, L.L. 2012 Drug effects: khat in biocultural and socioeconomic perspective. Left Coast Press, Walnut Creek, California, US.

Giles-Vernick, T. 2002 Cutting the vines of the past: environmental histories of the Central African rain forest. University Press of Virginia, Charlottesville, Virginia, US.

Gillespie, S. 2008 Poverty, food insecurity, HIV vulnerability, and the impacts of AIDS in sub-Saharan Africa. IDS Bulletin, on line library, 13.

Giri, K. and Darnhofer, I. 2010a Nepali women using community forestry as a platform for social change. Society and Natural Resources 23: 1216-1229.

Giri, K. and Darnhofer, I. 2010b Outmigrating men: a window of opportunity for women's participation in community forestry? Scandinavian Journal of Forest Research 25: 55-61.

Goebel, A. 2003 Gender and entitlements in the Zimbabwean woodlands: a case study of resettlement. In: Howard, P.L. Women and plants: gender relations in biodiversity management and conservation. Zed Books, New York.

Gondowarsito, R. 2002 Men, women and community development in East Nusa Tenggara. In: Robinson, K. and Bessell, S. Women in Indonesia: gender, equity and development. Institute of Southeast Asian Studies, Singapore.

Greenberg, L.S.Z. 2003 Women in the garden and kitchen: the role of cuisine in the conservation of traditional house lot crops among Yucatec Mayan immigrants. In: Howard, P.L. Women and plants: gender relations in biodiversity management and conservation. New York.

Gupte, M. 2004 Participation in a gendered environment: the case of community forestry in India. Human Ecology 32 (3): 365-382.

High Level Panel of Experts, HLPE. 2011 Land tenure and international investments in agriculture: a report by the High Level Panel of Experts on Food Security and Nutrition of the Committee on World Food Security. High Level Panel of Experts on Food Security and Nutrition of the Committee on World Food Security, Rome.

Hoffman, S. 2003 Arawakan women and the erosion of traditional food production. In: Howard, P.L. Gender relations in biodiversity management and conservation. Zed Books, New York. 
Hoskins, J. 1990 Doubling deities, descent and personhood: an exploration of Kodi gender categories. In: Atkinson, J.M. and Errington, S. (eds.) Power and difference: gender in Island Southeast Asia. Stanford University Press, Stanford, California, US.

Howard, P.L. (ed.) 2003 Women and plants: gender relations in biodiversity management and conservation. Zed Books, New York.

Hugo, G. 2002 Women's international labour migration. In: Robinson, K. and Bessell, S. (eds.) Women in Indonesia: gender, equity and development. Institute of Southeast Asian Studies, Singapore.

Hull, T.H. and Adioetomo, S.M. 2002 Women, family planning and decentralisation: new variations on old themes. In: Robinson, $\mathrm{K}$. and Bessell, S. (eds.) Women in Indonesia: gender, equity and development. Institute of Southeast Asian Studies, Singapore.

Hull, V.J. 1996 Women in Java's rural middle class: progress or regress? In: Van Esterik, P. (ed.) Women of Southeast Asia. Center for Southeast Asian Studies, Northern Illinois University, DeKalb, Illinois, US.

IRIN 2012 Nepal: Community forest value untapped. IRIN 12 September http:// www.irinnews.org/Report/96394/NEPALCommunity-forest-value-untapped IRIN

Jacobs, K., Namy, S., Kes, A., Bob, U. and Moodley, V. 2011 Gender differences in asset rights in KwaZulu-Natal, South Africa. International Center for Research on Women, Washington, DC.

Jacobsen, J.P. 2006 Men's issues in development. In: Bannon, I. and Correia, M.C. (eds.) The other half of gender: men's issues in development. World Bank, Washington, DC.

Jaquette, Jane S. 2010 Women's rights, indigenous rights, and social cohesion in Latin America. submitted to the United Nations Economic Commission for Latin America and the Caribbean (ECLAC or CEPAL): 26.

Jassal, S.T. 2012 Unearthing gender: folksongs of North India. Duke University, Durham, North Carolina, US.

Jayal, N.G. 2003 Locating gender in the governance discourse. In: Nussbaum, M., Basu, A., Tambiah, Y. and Jayal, N.G. (eds.) Essays on gender and governance. Human Development Resource Centre, United Nations Development Programme, New Delhi, India.
Jiggins, J. 1994 Changing the boundaries: womencentered perspectives on population and the environment. Island Press, Washington, DC.

Jordan, B. 1993 Birth in four cultures: a crosscultural investigation of childbirth in Yucatan, Holland, Sweden and the United States. Waveland Press, Prospect Heights, Illinois, US.

Kedit, P.M. 1993 'Meanwhile, Back Home....': bejalai and their effects on Iban men and women. In: Sutlive, V.H. (ed.) Female and male in Borneo: contributions and challenges to gender studies. Department of Anthropology, College of William and Mary, Williamsburg, Virginia, US.

Kelly, J.J. 2009 Reassessing forest transition theory: gender, land tenure insecurity and forest cover changes in rural El Salvador. Ph.D. Thesis. Rutgers University, New Brunswick, New Jersey, US.

Komarudin, H., Siagian, Y.L., Colfer, C.J.P. with, Neldysavrino, Yentirizal, Syamsuddin and Irawan, D. 2011 The role of collective action in securing property rights for the poor: A case study in Jambi Province, Indonesia. In: Mwangi, E., Markelova, H. and Meinzen-Dick, R. (eds.) Collective action and property rights for poverty reduction, University of Pennsylvania Press, Philadelphia, Pennsylvania, US.

Koopman, J. and Faye, I.M. 2012 Land grabs, women's farming and women's activism in Africa. In: International conference on global land grabbing II. Ithaca, New York, US.

Kothari, B. 2003 The invisible queen in the plant kingdom: gender perspectives in medical ethnobotany. In: Howard, P.L. (ed.) Women and plants: gender relations in biodiversity management and conservation. Zed books, New York.

Kusumanto, T., Yuliani, L., Macoun, P., Indriatmoko, Y. and Adnan, H. 2005 Learning to adapt: managing forests together in Indonesia. CIFOR, Bogor, Indonesia.

Lachapelle, P.R, Smith, P.D. and McCool, S.F. 2004 Access to power or genuine empowerment? An analysis of three community forest groups in Nepal. Human Ecology Review 11 (1): 1-12.

Laderman, C. 1987 Wives and midwives: childbirth and nutrition in rural Malaysia. University of California Press, Berkeley, California, US. 
Laderman, C. 1996 Putting Malay women in their place. In: Van Esterik, P. (ed.) Women of Southeast Asia, Northern Illinois University, DeKalb, Illinois, US.

Leach, M. 1992 Women's crops in women's spaces: gender relations in Mende rice farming. In: Croll, E. and Parkin, D. (eds.) Bush base: forest farm: culture, environment and development. Routledge, London.

Leach, M. 2007 Earth mother myths and other ecofeminist fables: how a strategic notion rose and fell. Development and Change 38 (1): 67-85.

Leach, M. and Mearns, R. (eds.) 1996 Lie of the land: challenging received wisdom on the African environment. International African Institute, Oxford, UK.

Leaman, D.J. 1996 The medicinal ethnobotany of the Kenyah of East Kalimantan (Indonesian Borneo), University of Ottawa.

Leve, L. 2007 'Failed development' and rural revolution in Nepal: rethinking subaltern consciousness and women's empowerment. Anthropological Quarterly 80 (1): 127-172.

Lewark, S., George, L. and Karmann, M. 2011 Study of gender equality in community based forest certification programmes in Nepal. International Forestry Review 13 (2): 195-204.

Lidestav, G. and Reed, M. 2010 Preface: gender and forestry. Scandinavian Journal of Forest Research 25 (S9): 1-5.

Lopez-Alzina, D.G. 2007 Gendered production space and crop varietal selection: a case study in Yucatan, Mexico. Singapore Journal of Tropical Geography 28: 21-38.

Lyon, L.M. and Hardesty, L.H. 2012 Quantifying medicinal plant knowledge among nonspecialist Antanosy villagers in southern Madagascar. Economic Botany 66 (1): 1-11.

Mabsout, R. and Van Staveren, I. 2010 Disentangling bargaining power from individual and household level to institutions: evidence on women's position in Ethiopia. World Development 38 (5): 783-796.

Mackenzie, A.F.D. 2005 Land tenure and biodiversity: an exploration in the political ecology of Murang' District, Kenya. In: Paulson, S. and Gezon, L.L. (eds.) Political ecology across spaces, scales and social groups. Rutgers University Press, New Brunswick, New Jersey, US.

MacLean, L. 2010 Informal institutions and citizenship in rural Africa: risk and reciprocity in Ghana and Côte d'Ivoire. Cambridge University Press, Cambridge, US.

MacLellan, J. 2009 Climate change adaptation for neophytes. In: Fenech, A. and MacLellan, J. (eds.) Linking climate and impact models to decision and policy making. Environment Canada, Toronto, Canada.

Mahat, I. 2003 Gender dimensions in household energy. Boiling Point 49: 27-29.

Marfo, E., Colfer, C.J.P., Kante, B. and Elias, S. 2010 From discourse to policy: the practical interface of statutory and customary land and forest rights. In: Larson, A., Barry, D., Dahal, G.R. and Colfer, C.J.P. (eds.) Forest for People: Community Rights and Forest Tenure Reform. Earthscan/CIFOR, London.

Mashman, V. 1993 Warriors and weavers: a study of gender relations among the Iban of Sarawak. In: Sutlive, V.H. (ed.) Female and male in Borneo: contributions and challenges to gender studies. The Borneo Research Council, Shanghai, VA, US.

Mashman, V. and Nayoi, P. 2013 The Bidayuh of Sarawak, gender, spirituality and swiddens. In: Cairns, M. (ed.) A growing forest of voices. Earthscan, London.

Mata, G. and Sasvári, A.A. 2009 Integrating gender equality and equity in access and benefitsharing governance through a rights-based approach. In: Campese, J., Sunderland, T., Greiber, T. and Oviedo, G. (eds.) Rights based approaches: exploring issues and opportunities for conservation. CIFOR, Bogor, Indonesia.

Mavanza, M. and Grossman, A.A. 2007 Conservation and family planning in Tanzania: the TACARE experience. Population and Environment 28: 267-273.

Medvecky, B. 2012 Report from SMART visit to Zambia. CIIFAD, Cornell University, Ithaca, NY, US.

Meinzen-Dick, R., van Koppen, B., Behrman, J., Karelina, Z., Akamandisa, V., Hope, L. and Wielgosz, B. 2012 Putting gender on the map: methods for mapping gendered farm management systems in sub-Saharan Africa IFPRI Discussion Paper 01153:52. International Food Policy Research Institute, Washington, DC.

Meola, C.A. 2012 The transformation and reproduction of gender structure: how participatory conservation impacts social organization in the Mamirauá Sustainable Development Reserve, Amazonas, Brazil. Ph.D. Thesis, Cornell University, Ithaca, NY, US. 
Miller, J.F. 2009 Husband-assisted birth among the Rarámuri of northern Mexico. In: Inhorn, M.C., Tjornhoj-Thomsen, T., Goldbert, H. and Mosegaard, M.I.C. (eds.) Reconceiving the second sex: men, masculinity and reproduction. Berghahn Books, New York.

Moore, D.S. 1993 Contesting terrain in Zimbabwe's eastern highlands: political ecology, ethnography, and peasant resource struggles. Economic Geography 69 (4): 380-401.

Moore, L.J. 2009 Killer sperm: masculinity and the essence of male hierarchies. In: Inhorn, M. C., Tjornhoj-Thomsen, T., Goldberg, H. and Mosegaard M.I. C. (eds.) Reconceiving the Second Sex: Men, Masculinity, and Reproduction, 45-71. New York: Berghahn. Mukul, S.A., Rashid, A.Z.M.M., Quazi, S.A., Uddin, M.B. and Fox, J. 2012 Local peoples' responses to comanagement regime in protected areas: a case study from Satchari National Park, Bangladesh. Forests, Trees and Livelihoods 21 (1) : 16-29.

Murphy, Y. and Murphy, R.F. 2004 Women of the forest: thirtieth anniversary ed. Columbia University Press, New York.

Mustalahti, I. 2011 Gender and REDD+: taking note of past failures. In: Aguilar, L., QuesadaAguilar, A. and Shaw, D.D.M.P. (eds.) Forests and gender. International Union for Conservation of Nature in collaboration with The Woman Environment and Development Organization, Gland, Switzerland.

Mutimukuru-Maravanyika, T. 2010 Can we learn our way to sustainable management? Adaptive collaborative management in Mafungautsi State Forest, Zimbabwe, CERES Research School for Resource Studies for Development, Wageningen University, Wageningen, The Netherlands.

Mwangi, E. and Mai, Y.H. 2011 Introduction to the special issue on forests and gender. International Forestry Review 13 (2): 119-122.

Mwangi, E., Meinzen-Dick, R. and Sun, Y. 2011 Gender and sustainable forest management in East Africa and Latin America. Ecology and Society 16 (1): 17.

Naeher, L.P., Brauer, M., Lipsett, M., Zelikoff, J.T., Simpson, C.D., Koening, J.Q. and Smith, K.R. 2007 Woodsmoke health effects: a review. Inhalation Toxicology 19: 67-106.

Nakro, V. and Kikhi, C. 2006 Strengthening market linkages for women vegetable vendors: experiences from Kohima, Nagaland, India. In: Vernooy, R. (ed.) Social and gender analysis in natural resource management: learning studies and lessons from Asia. Sage Publications, New Delhi, India.

Nascimento, V.T. do, da Silva Vasconcelos, M.A., Maciel, M.I.S. and Albuquerque, U.P. 2012 Famine foods of Brazil's seasonal dry forests: ethnobotanical and nutritional aspects. Economic Botany 66 (1): 22-34.

Nemarundwe, N. 2005 Women, decision making and resource management in Zimbabwe. In: Colfer, C.J.P. The equitable forest: diversity, community and resource management, Resources for the Future/CIFOR, Washington, DC.

Nemarundwe, N., De Jong, W. and Cronkleton, P. 2003 Future scenarios as an instrument for forest management. CIFOR, Bogor, Indonesia.

Ngono, D.L. and Ardayfio-Schandorf, E. 2007 Gender mainstreaming in forestry in Africa. Food and Agriculture Organization of the United Nations, Rome.

Nightingale, A. 2003 A feminist in the forest: situated knowledges and mixing methods in natural resource management. ACME: An International E-Journal for Critical Geographies 2 (1).

Nightingale, A J. 2011 Bounding difference: intersectionality and the material production of gender, caste, class and environment in Nepal. Geoforum 42 (2): 153-162.

Noerdin, E. 2002 Customary institutions, Syariah law and the marginalisation of Indonesian women. In: Robinson, K. and Bessell, S. (eds.) Women in Indonesia: gender, equity and development. Institute of Southeast Asian Studies, Singapore.

Noss, A.J. and Hewlett, B.S. 2001 The contexts of female hunting in Central Africa. American Anthropologist 103 (4): 1024-1040.

Novellino, D. 2013 Rice-related knowledge, farming strategies and the transformation of swiddens amongst the Batak of Palawan Island, the Philippines. In: Cairns, M. (ed.) A growing forest of voices. Earthscan, London.

Nussbaum, M. 2003 Gender and governance: an introduction. In: Nussbaum, M., Basu, A., Tambiah, Y. and Jayal, N.G. (eds.) Essays on gender and governance. Human Development Resource Centre, United Nations Development Programme, New Delhi, India. Nussbaum, M. Basu, A., Tambiah, Y. and Jayal, N.G. (eds.) 2003 Essays on gender and 
governance. Human Development Resource Centre, United Nations Development

Programme, New Delhi, India.

Oey-Gardiner, M. 2002 And the winner is...Indonesian women in public life. In: Robinson, K. and Bessell, S. (eds.) Women in Indonesia: gender, equity and development, Institute for Southeast Asian Studies, Singapore.

Oxfam 2010 Gender, disaster risk reduction and climate change adaptation: a learning companion. Oxfam Disaster Risk Reduction and Climate Change Adaptation Resources: 15.

Organisation for Economic Co-operation and Development (OECD) 2010 Atlas of gender and development: how social norms affect gender equality in non-OECD Countries. OECD Publishing, Paris.

Padmanabhan, M.A. 2007 The making and unmaking of gendered crops in northern Ghana. Singapore Journal of tropical geography 28 (1): 57-70.

Pandolfelli, L., Meinzen-Dick, R. and Dohrn, S. 2007 Gender and collective action: a conceptual framework for analysis. Collective Action Working Paper 64:57.

Paulson, S. and Gezon, L.L. (eds.) 2004 Political ecology across spaces, scales and social groups. Rutgers University Press, New Brunswick, NJ, US.

Permatasari, E. 2007 Baru Pelepat village, Jambi: Lubuk Larangan and women. In: Yuliani, E.L., Tadjudin, D., Indriatmoko, Y., Munggoro, D.W., Gaban, F., Maulana, F. and Adnan, H. (eds.) Multistakeholder forestry: steps to change. CIFOR, Bogor, Indonesia.

Pierce, C. 1971 Natural law language and women. In: Gornick, V. and Moran, B.K. Woman in sexist society: studies in power and powerlessness. Basic Books, New York.

Pigg, S.L. 1996 The credible and the credulous: the question of 'villagers' beliefs' in Nepal. Cultural Anthropology 11 (2): 160-201.

Porro, N.M. and Stone, S. 2005 Diversity in living gender: two cases from the Brazilian Amazon. In: Colfer, C.J.P. (ed.) The equitable forest: diversity, community and resource management. Resources for the Future/CIFOR, Washington, DC.

Pottinger, A. J. and Mwangi, E. 2011 Special issue: forests and gender. The International Forestry Review 13 (2): 1-258.
Pruitt, L.R. 2009 Migration, development and the promise of CEDAW for rural women. Michigan Journal of International Law 30: 1-57.

Purnomo, H., Irawati, R.H., Fauzan, A.U. and Melati, M. 2011 Scenario-based actions to upgrade small-scale furniture producers and their impacts on women in Central Java, Indonesia. International Forestry Review 13 (2):163-176.

Quisumbing, A.R., Otsuka, K. with Suyanto, S., Aidoo, J.B. and Payongayong, E. 2001 Land, trees and women: evolution of land tenure Institutions in Western Ghana and Sumatra. IFPRI Research Report 121: 1-90.

Quisumbing, A.R., Payongayong, E.M. and Otsuka, K. 2004 Are wealth transfers biased against girls? Gender differences in land inheritance and schooling investment in Ghana's western region. Food Consumption and Nutrition Division Discussion Paper 186.

Redfield, R. 1971 (original 1960) The little community, peasant society and culture. University of Chicago Press, Chicago, US.

Reed, M.G. 2010 Guess who's (not) coming for dinner: expanding the terms of public involvement in sustainable forest management. Scandinavian Journal of Forest Research 25 (S9): 45-54.

Reed, M.G. and Bruyneel, S. 2009 Rescaling environmental governance, rethinking the state: a three-dimensional review. Progress in Human Geography: 1-7.

Reed, M.G. and Christie, S. 2008 Environmental geography: we're not quite home - reviewing the gender gap. Progress in Human Geography 33 (2): 246-255.

Richards, P. 2006 Young men and gender in war and postwar reconstruction: some comparative findings form Liberia and Sierra Leone. In: Bannon, I. and Correia, M.C. (eds.) The other half of gender: men's issues in development. World Bank, Washington, DC.

Roberts, M. 2013 The bigger picture: swidden, non-timber forest products and livelihoods in Northern Lao PDR. In: Cairns, M. (ed.) A growing forest of voices. Earthscan, London.

Rocheleau, D. 1991 Gender, ecology and the science of survival: stories and lessons from Kenya. Agriculture and Human Values (Winter-Spring) 8: 156-65.

Rocheleau, D., Thomas-Slayter, B. and Wangari, E. (eds.) 1996 Feminist political ecology: global issues and local experiences. Routledge, London. 
Rudel, T.K. 2005 Tropical forests: regional paths of destruction and regeneration in the late twentieth century. Columbia University Press, New York.

Ruiz Pérez, M., Ndoye, O., Eyebe, A. and Ngono, D.L. 2002 A gender analysis of forest product markets in Cameroon. Africa Today 49 (3): 97-126.

Russell, D. and Tchamou, N. 2001 Soil fertility and the generation gap: the Bene of southern Cameroon. In: Colfer, C.J.P. (ed.) People managing forests: the links between human well being and sustainability. Resources for the Future/CIFOR, Washington, DC.

Sachs, C. 1996 Gendered fields: rural women, agriculture and environment. Rural Studies Series, Westview Press, Boulder, CO, US.

Sajise, P.E. 2013 Biodiversity and swidden agroecosystems: an analysis and some implications. In: Cairns, M. (ed.) A growing forest of voices. Earthscan, London.

Sarin, M. 2000 'Should I use my hands as fuel?' In: Kabeer, N. and Subrahmanian, R. (eds.) Institutions, relations and outcomes: a framework and case studies for gender-aware planning. Zed Books, London.

Schroeder, R.A. 1999 Shady practices: agroforestry and gender politics in the Gambia. University of California Press, Berkeley, US.

Scott, J.C. 2009 The art of not being governed: an anarchist history of Upland Southeast Asia. Yale University Press, New Haven, CT, US.

Sen, H.T. and An, L.V. 2006 Creating opportunities for change: strengthening the social capital of women and the poor in Upland communities in Hue, Viet Nam. In: Vernooy, R. (ed.)

Social and gender analysis in natural resource management: learning studies and lessons from Asia. Sage Publications, London, UK.

Shackleton, S., Paumgarten, F., Kassa, H., Husselman, M. and Zida, M. 2011

Opportunities for enhancing poor women's socio-economic empowerment in the value chains of three African non-timber forest products (NTFPs). International Forestry Review 13 (2): 136-151.

Shanley, P.F., Da Silva, C. and Macdonald, T. 2011 Brazil's social movement, women and forests: a case study from the National Council of Rubber Tappers. International Forestry Review 13 (2): 233-244.

Shipton, P. 2007 The nature of entrustment: intimacy, exchange, and the sacred in Africa. Yale University Press, New Haven, CT, US.
Shiva, V. 1989 Staying alive: women, ecology and development. Zed Books, London.

Silberschmidt, M. 2001 Disempowerment of men in rural and urban East Africa: implications for male identity and sexual behaviour. World Development 29 (4): 657-671.

Sithole, B. 2005 Becoming men in our dresses! Women's involvement in a joint forestry management project in Mafungautsi, Zimbabwe. In: Colfer, C.J.P. (ed.) The equitable forest: diversity, community and resource management. Resources for the Future/CIFOR, Washington, DC.

Sommers, M. 2006 Fearing Africa's young men: male youth, conflict, urbanization and the case of Rwanda. In: Bannon, I. and Correia, M.C. (eds.) The other half of gender: men's issues in development. World Bank, Washington, DC.

Stevens Jr., P. 2006 Women's aggressive use of genital power in Africa. Transcultural Psychiatry 43: 592-599.

Sun, Y., Mwangi, E. and Meinzen-Dick, R. 2011 Is gender an important factor influencing user groups' property rights and forestry governance? Empirical analysis from East Africa and Latin America. International Forestry Review 13 (2): 205-219.

Sutlive, V.H. (ed.) 1993 Female and male in Borneo: contributions and challenges to gender studies. Borneo Research Council, Inc., Williamsburg, VA, US.

Suyanto, S., Tomich, T.P. and Otsuka, K. 2001 Agroforestry management in Sumatra. In: Otsuka, K. and Place, F. (eds.) Land tenure and natural resource management: a comparative study of agrarian communities in Asia and Africa. Johns Hopkins University Press, Baltimore, MD, US.

Tambiah, Y. 2003 The impact of gender inequality on governance. In: Nussbaum, M., Basu, A., Tambiah, Y. and Jayal, N.G. (eds.) Essays on gender and governance. Human Development Resource Center, UNDP, New Delhi, India.

Terry, G. 2009 Introduction. In: Terry, G. (ed.) Climate change and gender justice. Oxfam, Oxford, UK.

Tiani, A.M, Akwah, G. and Nguiébouri, J. 2005 Women in Campo-Ma'an National Park: uncertainties and adaptations in Cameroon. In: Colfer, C.J.P. (ed.) The equitable forest: diversity, community and resource management. Resources for the Future/ CIFOR, Washington, DC. 
Timsina, N.P. 2003 Promoting social justice and conserving montane forest environments: a case study of Nepal's community forestry programme. The Geographical Journal 169 (3): 236-242.

Torri, M.C. 2010 Power, structure, gender relations and community-based conservation: the Cawswe study of the Sariska region, Rajasthan, India. Journal of International Women's Studies 11 (4): 1-19.

Torri, M.C. 2012 Mainstreaming local health through herbal gardens in India: a tool to enhance women active agency and primary health care? Environmental Development and Sustainability 14: 389-406.

Tripathi, R. et al. 2012 What works for women: proven approaches for empowering women smallholders and achieving food security. ActionAid International, Christian Aid, Concern Worldwide, Find Your Feet, Oxfam, Practical Action, Save the Children, Self Help Africa.

Tsing, A.L. 1990 Gender and performance in Meratus dispute settlement. In: Atkinson, J.M. and Errington, S. (eds.) Power and difference: gender in Island Southeast Asia. Stanford University Press, Stanford, CA, US.

Tsing, A.L. 1993 In the realm of the diamond queen. Princeton University Press, Princeton, NJ, US.

Tsing, A.L. 2005 Friction: an ethnography of global connection. Princeton University Press, Princeton, NJ, US.

UN-REDD Programme 2011 The business case for mainstreaming gender in REDD+. United Nations Development Programme (UNDP), Food and Agriculture Organization of the United Nations (FAO), United Nations Environment Programme (UNEP), Geneva, Switzerland.

van Esterik, P. 2008 Food culture in Southeast Asia. Greenwood Press, Westport, US.

Vernooy, R. (ed.) 2006 Social and gender analysis in natural resource management: learning studies and lessons from Asia. Thousand Oaks, New Delhi, India.
Veuthey, S. and Gerber, J-F. 2010 Logging conflicts in southern Cameroon: a feminist ecological economics perspective. Ecological Economics 70: 170-177.

Voeks, R.A. 2007 Are women reservoirs of traditional plant knowledge? Gender, ethnobotany and globalization in northeast Brazil. Singapore Journal of Tropical Geography 28 (1): 7-20.

Wan, M., Colfer, C.J.P. and Powell, B. 2011 Forests, women and health: opportunities and challenges for conservation. International Forestry Review 13 (3): 369-387.

Wollenberg, E., Edmunds, D. and Buck, L.E. 2001 Anticipating change: scenarios as a tool for increasing adaptivity in multistakeholder settings. In: Buck, L.E., Geisler, C.C., Schelhas, J. and Wollenberg, E. (eds.) Biological diversity: balancing interests through adaptive collaborative management. CRC Press, Boca Raton, LA, US.

Women Organizing for Change in Agriculture and Natural Resources (WOCAN) 2012 An assessment of gender and women's exclusion in REDD+ in Nepal. WOCAN Working Paper 11, Bangkok, Thailand.

Wooten, S. 2003 Losing ground: gender relations, commercial horticulture and threats to local plant diversity in rural Mali. In: Howard, P. (ed.) Women and plants, gender relations in biodiversity management and conservation. Zed Books, London.

World Bank 2009 Module 10: Gender and natural resource management, overview. In: Gender in agriculture sourcebook, World Bank, Washington, DC.

World Bank 2011 World development report 2012: gender equality and development. World Bank, Washington, DC.

Yen, A. 2009 Reproductive politics in southwest China: deconstructing a minority maledominated perspective on reproduction. In: Inhorn, M.C., Tjornhoj-Thomsen, T., Goldberg, H. and Mosegaard, M.I.C. (eds.) Reconceiving the second sex: men, masculinity and reproduction. Berghahn, New York. 


CIFOR Occasional Papers contain research results that are significant to tropical forestry. The content is peer reviewed internally and externally.

This document is designed to aid foresters and other natural resource managers to more effectively integrate gender into (primarily tropical) forest management. It identifies 11 issues highlighted in the literature on gender. Each issue, though relevant at all scales-macro, meso and micro-is examined at a particular scale, as shown in the 'gender box'. The purpose is to highlight both the importance of and the interactions among scales, as we consider the lives of individual women and men in forests. Extensive reference is made to the literature, both as a guide for users and as a mechanism to show clearly what gender researchers have found relevant to each issue. Brief suggestions for ways forward are provided in closing.

This research was carried out by CIFOR as part of the CGIAR Research Program on Forests, Trees and Agroforestry. This collaborative program aims to enhance the management and use of forests, agroforestry and tree genetic resources across the landscape from forests to farms. CIFOR leads the program in partnership with Bioversity International, CIRAD (Centre de coopération internationale en recherche agronomique pour le développement), the International Center for Tropical Agriculture and the World Agroforestry Centre. 